Historical Resources of the Choke Canyon Reservoir Area in McMullen and Live Oak Counties, Texas; Historical Archaeological Resources of the Choke Canyon Reservoir Area in McMullen and Live Oak Counties, Texas

\author{
Dianna Everett \\ Center for Archaeological Research \\ Philip A. Bandy \\ Center for Archaeological Research
}

Follow this and additional works at: https://scholarworks.sfasu.edu/ita

Part of the American Material Culture Commons, Archaeological Anthropology Commons, Environmental Studies Commons, Other American Studies Commons, Other Arts and Humanities Commons, Other History of Art, Architecture, and Archaeology Commons, and the United States History Commons

Tell us how this article helped you.

This Article is brought to you for free and open access by the Center for Regional Heritage Research at SFA ScholarWorks. It has been accepted for inclusion in Index of Texas Archaeology: Open Access Gray Literature from the Lone Star State by an authorized editor of SFA ScholarWorks. For more information, please contact cdsscholarworks@sfasu.edu. 
Historical Resources of the Choke Canyon Reservoir Area in McMullen and Live Oak Counties, Texas; Historical Archaeological Resources of the Choke Canyon Reservoir Area in McMullen and Live Oak Counties, Texas

Creative Commons License

(c) (1) (9)

This work is licensed under a Creative Commons Attribution-NonCommercial 4.0 International License 


\section{HISTORICAL RESOURCES OF THE CHOKE CANYON RESERVOIR AREA IN McMULLEN AND LIVE OAK COUNTIES, TEXAS}

By

Dianna Everett

\section{HISTORICAL ARCHAEOLOGICAL RESOURCES OF THE CHOKE CANYON RESERVOIR AREA IN MCMULLEN AND LIVE OAK COUNTIES, TEXAS}

By

Philip A. Bandy

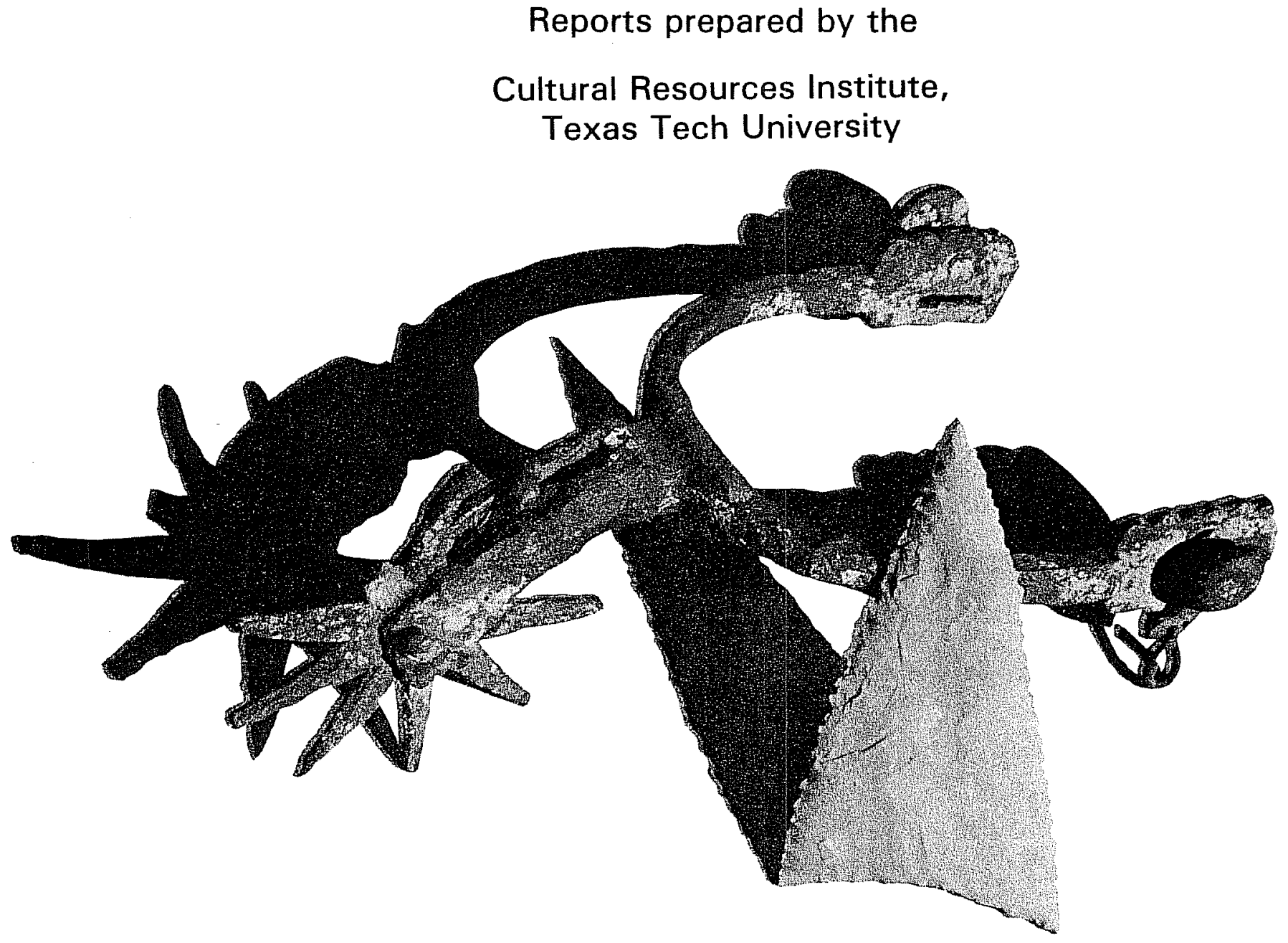

Center for Archaeological Research

The University of Texas at San Antonio

Choke Canyon Series: Volume 2 

HISTORICAL RESOURCES OF THE

CHOKE CANYON RESERVOIR AREA IN

MCMULLEN AND LIVE OAK COUNTIES, TEXAS

By

Dianna Everett

HISTORICAL ARCHAEOLOGICAL RESOURCES OF THE

CHOKE CANYON RESERVOIR AREA IN

MCMULLEN AND LIVE OAK COUNTIES, TEXAS

By

Philip A. Bandy

Reports prepared by the

Cultural Resources Institute,

Texas Tech University

Center for Archaeological Research

The University of Texas at San Antonio

Choke Canyon Series: Volume 2 Gmitgr for Arthadogical Research

1981

The Unversity of Toxas at San Antonio

San Antonio, Texas 78285 
Center for Archaeological Research

The University of Texas at San Antonio

78285

Thomas R. Hester, Director

\begin{abstract}
Volumes in the Phase I Choke Canyon Series.
Volume 1 Historic Indian Groups of the Choke Canyon Reservoir and Surrounding Area, Southern Texas. By T. N. Campbell and T. J. Campbell.

Volume 2 Part I - Historical Resources of the Choke Canyon Reservoir Area in McMullen and Live Oak Counties, Texas. By Dianna Everett.

Part II - Historical Archaeological Resources of the Choke Canyon Reservoir Area in McMullen and Live Oak Counties, Texas. By Philip A. Bandy.

Volume 3 An Archaeological Survey of a Portion of the Choke Canyon Reservoir Area in McMullen and Live Oak Counties, Texas. By Alston V. Thoms, John L. Montgomery, and Alice W. Portnoy.

Volume 4 The 1979 Archaeological Survey of Portions of the Choke Canyon Reservoir in Live Oak and McMullen Counties, Texas. By Erwin Roemer, Jr.

Volume 5 Archaeological Investigations at Choke Canyon Reservoir, South Texas: The Phase I Findings. By Grant D. Hall, Carol Graves, and Stephen L. Black.

Volume 6 Archaeological Testing and Collecting at Choke Canyon Reservoir, Nueces River Project, Texas. By Carol S. Weed and Harry J. Shafer.

Volume 7 Excavations at $41 \mathrm{LK}$ 67, A Prehistoric Site in the Choke Canyon Reservoir, South Texas. By Grant D. Hall.

Volume 8. Excavations at Sites $41 \mathrm{LK} 31 / 32$ and $41 \mathrm{LK} 202$ in the Choke Canyon Reservoir, South Texas. By Robert F. Scott IV and Daniel E. Fox.

Volume 9 Phase I Archaeological Investigations at Choke Canyon Reservoir, South Texas: A Summary and Synthesis. By T. R. Hester and Grant D. Hall.
\end{abstract}

NOTE: Titles of the above volumes are only tentative and may change at time of publication. 
LIST OF CHARTS . . . . . . . . . . . . . . . . . . . . . iii

LIST OF FIGURES . . . . . . . . . . . . . . . . . . . . . iii

LIST OF TABLES ............................. iv PREFACE ................................ v FOREWORD ............................. . . . vi

PART I: HISTORICAL RESOURCES OF THE CHOKE CANYON RESERVOIR AREA

IN MCMULLEN AND LIVE OAK COUNTIES, TEXAS. . . . . . . . . xiii

ABSTRACT . . . . . . . . . . . . . . . . . . . . . . XV

ACKNOWLEDGMENTS. . . . . . . . . . ................ xvi

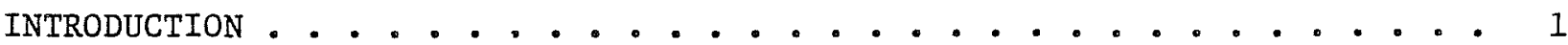

Historical Approach . . . . . . . . . . . . . . . . . . . 1

Research Procedures ....................... . . 3

Report Preparation ....................... . . . 4 4

HISTORICAL BACKGROUND. . . . . . . . . . ........ . 5

Early Colonization Efforts . . . . . . . . . . . . . . 5

Exploration, 1842-1849. . . . . . . . . . . . . . . . 6

Urban Frontier . . . . . . . . . . . . . . . . . . . 8

Yarbrough Bend, 1858-1880 . . . . . . . . . . . . . 9

Settlement and Subsistence, 1860-1870 . . . . . . . . . . 13

Settlement and Subsistence, 1870-1890 . . . . . . . . . . 17

The Twentieth Century . . . . . . . . . . . . . . . . . 22

Genealogy . . . . . . . . . . . . . . . . . . . . 23

Summary . . . . . . . . . . . . . . . . . . . . . 26

Notes . . . . . . . . . . . . . . . . . . . 28

LIVE OAK COUNTY ARCHEOLOGICAL SITE HISTORIES . . . . . . . . . . . . . . 34

Site 4llK66 (Nichols House) . . . . . . . . . . . . . . 34

Sites 4lLK197, 199. . . . . . . . . . . . . . . . 34

Sites 4lLK73, 53 (Prehistoric). . . .............. 35

Site $41 \mathrm{LK} 15$. . . . . . . . . . . . . . . . . 36

Sites 4lLK159, 168 . . . . . . . . . . . . . . . . 37

Notes . . . . . . . . . . . . . . ........ . . 39

MCMULLEN COUNTY ARCHEOLOGICAL SITE HISTORIES . . . . . . . . . . . . 41

Sites 41MC192 (Dusek), 193 (Bracken), 194 (Horton). . . . . . . . . 41 
Site 41MC195 (Teal House). . . . . . . . . . . . . . . 42

Sites 41MC15, 17, 71, 72 ("New"), 193, 74 (Cemetery) ....... . 42

Yarbrough Bend Cemetery (no number assigned) . . . . ... . . 43

Site 41MC91........................... . 44

Sites 41MC166, 168 (Prehistoric) . . . . . . . . . . . . . 45

Sites 41MC66 (Byrne Ranch Cemetery), 55 (Prehistoric). . . . . . 46

Site 4IMC4 (Gravesite) . . . . . . . . . . . . . . . 47

Site 41MC6 (Gravesite) . . . . . . . . . . . . . . . . 48

Sites 41MC175, 46. . . . . . . . . . . . . . . . . . 48

Site 41MC185 ........................ . . 49

Site 41MC214 ......................... 50

Notes. . . . . . . . . . . . . . . . . . . . 51

REFERENCES CITED ............................ 57

INTERVIEWS. . . . . . . . . . . . . . . . . . . . . . 64

PART II: HISTORICAL ARCHAEOLOGICAL RESOURCES OF THE CHOKE CANYON

RESERVOIR AREA IN MCMULLEN AND LIVE OAK COUNTIES, TEXAS . . . 67

ABSTRACT. . . . . . . . . . . . . . . . . . . . 69

ACKNOWLEDGMENTS ........................... . . 70

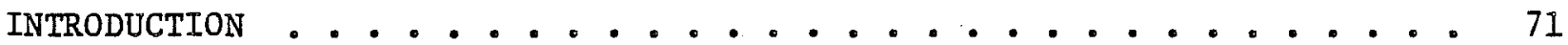

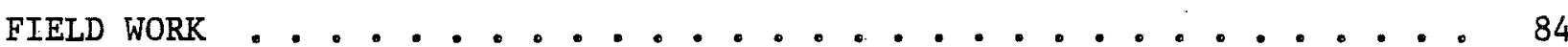

Surface Collections. . . . . . . . . . . . . . . . 84

Excavations . . . . . . . . . . . . . . . 84

Supra-surface Investigations . . . . . . . . . . . . 85

LABORATORY ACTIVITIES . . . . . . . . . . . . . . . . 86

ARTIFACT DESCRIPTION AND CLASSIFICATION . . . . . . . . . . . 88

Ceramic. . . . . . . . . . . . . . . . . 88

Glass. . . . . . . . . . . . . . . . . . 124

Metal. ........................ 125

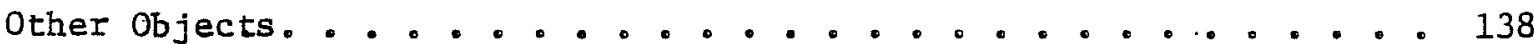

Prehistoric Artifacts....................... 138

SITE DESCRIPTIONS . . . . . . . . . . . . . . . . . . . . 139

41 L66 Nichols House (Surface Collection and Intensive Testing). . . 139

$41 \mathrm{MC15}$ (Surface Collection and Intensive Testing). . . . . . . 146

$41 \mathrm{MCl} 7$ (Surface Collection and Intensive Testing). . . . . . . 151

4 IMC46 (Surface Collection and Mapping). . . . . . . . . 154 
41MC72, "New" Site (Surface Collection and Intensive Testing). . . . . 158 41MC74 (Surface Collection and Intensive Testing). . . . . . . . 158 41MC91 (Surface Collection and Mapping). . . . . . . . . . . 162 41MC166, "Dump" Site (Surface Collection and Mapping). . . . . . . 167 41MC168, Teal Site (Surface Collection and Mapping). . . . . . . 167 41MC175 (Surface Collection and Mapping) . . . . . . . . . . . 168 41MC185 (Surface Collection and Intensive Testing) . . . . . . . . 174 41MC192, Dusek Site (Surface Collection and Intensive Testing) . . . 177 41MC193, Bracken Site (Surface Collection and Mapping) . . . . . . 182 41MC194, Horton Site (Surface Collection and Mapping). . . . . . . 184 41MC195, Teal House (Surface Collection) . . . . . . . . . . . 186 SUMMARY AND CONCLUSIONS . . . . . . . . . . . . . . . . 187 REFERENCES CITED . . . . . . . . . . . . . . . . . . . 189

\section{LIST OF CHARTS}

1. Project Organization ..................... vii

2. TTU Nueces River Project ...................... . viii

3. TTU Nueces River Project Milestone Chart . . . . . . . . . . . . x

\section{LIST OF FIGURES}

1. Choke Canyon Reservoir Area . . . . . . . . . . . . 2

2. Exploration of South Texas................... . 7

3. Project Area, 1870..................... . . 18

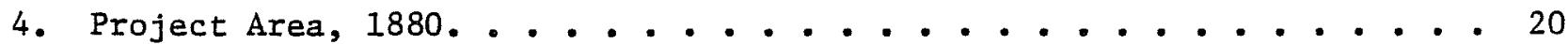

5. Project Area Map with Sites Located . . . . . . . . . . . . 72

6. Various Ceramics: earthenware, stoneware, and porcelain. . . . . . 116

7. Stoneware Ceramics and Metal Artifacts. . . . . . . . . . . . 119

8. Wrought Metal, Stoneware, and Household Artifacts . . . . . . . . 121

9. Stoneware and Household Items . . . . . . . . . . . . . . 123

10. Household and Metal Artifacts . . . . . . . . . . . . 133

11. Metal Items, Gun Parts and Ammunition . . . . . . . . . . . . . 134

12. Map of Site 4lLK66 - Nichols House . . . . . . . . . . . . . . 140 
Page

13. Test Pit 2 and North Outbuilding, 4lik66 ............. 141

14. Elevations of Extant House, 4llK66 . . . . . . . . . . . . . 142

15. Floor Plan of Nichols House, 4lLK66..... . . . . . . . . 143

16. Site Map of 41MC15 . . . . . . . . . . . . . . . . . 。 147

17. Plan Map of Sandstone, 41MC15. . . . . . . . . . . . . . . 148

18. Photographs of Various Features. . . . . . . . . . . . . . 149

19. Site Map of 41MC17 . . . . . . . . . . . . . . . . . 152

20. Plan of Sandstone and Excavation Units, Area A, 41MC17 . •. . . . 153

21. Details of East Profile Unit 1 and Chimney Plan, 41MC17. . . . . 155

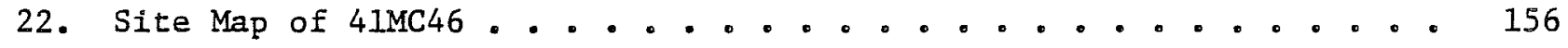

23. Site Map of 41MC72 ...................... . . . 159

24. Site Map of 41MC74 ........................ 160

25. Site Map of 41MC91 . . . . . . . . . . . . . . . . . 163

26. Photographic Views of 41MC91 and 41MC185 ............. . 164

27. Cistern Plan, 4lMC91 . . . . . . . . . . . . . . . . . 165

28. Artifacts from 41MC168 and 41MC192 ................. 169

29. Site Map of 41MC175 . . . . . . . . . . . . . . . . . . 170

30. Elevations of Extant House, 41 MCI75 .................. 172

31. Floor Plan of 41MC175. . . . . . . . . . . . . . . . . 173

32. Site Map of 41MC185 . . . . . . . . . . . . . . . . . 175

33. Site Map of $41 M C 192$ (the Dusek Site) . . . . . . . . . . . . . 178

34. Photographs of 41MC192 . . . . . . . . . . . . . . . . 179

35. Chimney Foundation and South Profile, 41MC192. . . . . . . . . . 180

36. Bracken Site Sketch Map, 4IMC193 . . . . . . . . . . . . 183

37. Site 41MC193 . . . . . . . . . . . . . . . . 185

\section{LIST OF TABLES}

1. Genealogy Chart, Teal and Yarbrough Families . . . . . . . . . . 24

2. Historic Sites Studied, TTU-CRI Project 1977-78. ......... 73

3. Description of Sites . . . . . . . . . . . . . . . . 74

4. CRI-TTU 1977 Field Work. . . . . . . . . 。 . . 。 . . 。 77

5. Suggested Culture/Chronology . ................. 79

6. Artifact Classification Outline. . . . . . . . . . . . . 90

7. Artifact Inventory . . . . . . . . . . . . . . . . . 92

8. Site Chronology Chart. . . . . . . . . . . . . . . . . 126

9. Nail Totals from Each Site . . . . . . . . . . . . . . 136 
PREFACE

This is the second in a series of volumes published on the cultural resources of the Choke Canyon reservoir area of southern Texas. Research has been underway in the reservoir basin since 1977 under the terms of Contract No. 7-07-50-V0897 (Nueces River Project) between the Center for Archaeological Research, The University of Texas at San Antonio and the Bureau of Reclamation of the United States Department of the Interior. The original contract constituted Phase I of the cultural resource investigations. During Phase I, the Cultural Resources Institute of Texas Tech University worked under a subcontract with the Center for Archaeological Research in carrying out a program that involved a study of the area's history, an examination of the historical archaeology, and a site survey. This volume, along with Volume 3 of the Choke Canyon Series, fulfills the subcontract agreement of Texas Tech University.

Part I of the present volume is the work of a professional historian and follows a format standard among historians. For example, the citations of references differ from those typical of an archaeological report format as seen in Part II. The careful reader will notice other aspects of style and format in this volume that differ from previously published reports of the Center for Archaeological Research; this reflects the fact, that the manuscript was typed in final form by the Cultural Resources Institute at Texas Tech. We have, however, modified the bibIiographies to conform to Center format.

Part I, by Dianna Everett, is an important summary of the history of the Choke Canyon region. It can be used in conjunction with Volume 1 , dealing with the historic Indian populations, to obtain an overview of the historic cultural patterns of the region. Part II, authored by Philip A. Bandy, is a detailed study of historical sites investigated under the Cultural Resources Institute subcontract. It is a major contribution to the understanding of early Anglo-Hispanic utilization of what is now Live Oak and McMullen Counties.

Sharon G. Quirk

Thomas R. Hester

August 27, 1981 
FOREWORD

Early in 1977 the Bureau of Reclamation RFP 50-V0897 for Cultural Resource Investigations became available to us at the Cultural Resources Institute of Texas Tech University. The geographic focus of this RFP was the Nueces River, Texas project (specifically concerned with dam construction at Choke Canyon) and the topical needs were both archeological and historical. Because the scope of this project was quite extensive and because of the previous work in that general area by The University of Texas at San Antonio, we discussed the project with Dr. Thomas Hester, Director of the Center for Archaeological Research at The University of Texas at San Antonio. Agreement was reached on a division of labor among three institutions (The University of Texas at San Antonio, Texas A \& M, and Texas Tech). On March 14, 1977 we formalized this in a proposal (Mayer-Oakes 1977) submitted to The University of Texas at San Antonio for a subcontract which would enable Texas Tech University to join with Texas A \& $M$ and The University of Texas at San Antonio in carrying out the total project required by the Bureau of Reclamation. The general framework agreed on was that of a prime contractor associated with two subcontractors. This is shown schematically in Chart 1 from that proposal.

The Bureau of Reclamation's Scope of Work for this project specified eight items (pp. 1-3 of "Technical Data" part of the RFP) to be accomplished. The eight items were:

1. Intensive recovery of 3 prehistoric sites.

2. Intensive testing of 15 prehistoric sites.

3. Minimal testing of 41 prehistoric sites.

4. Surface collection of 73 prehistoric sites.

5. Intensive testing of 4 historic sites.

6. Surface collection of 6 historic sites.

7. Completion of intensive survey of 8000 acres.

8. Historic and ethnohistoric search.

Discussions with Dr. Hester led to agreement that TTU would put together a complex of four (4) project units which would cover 4 of the 8 items specified in the Scope of Work. The four items proposed to be handled by TTU were items 5 , 6,7 , and 8 .

In addition, because of the large scale of the project, tight time schedule required and the complexities of topical interrelationships required, we proposed a "management" project to assist in the necessary coordination among all the TTU projects. Our reasons for wanting to have an explicit management project were twofold: First, we had already carried out some similar activities in proposal and project analysis (Radium Springs, New Mexico), and in laboratory project scheduling (Canyon Lake, Texas); second, we had been involved with theoretical usage of the concepts of Critical Path Method and PERT as management tools (cf. Fox and Alexander 1978; Alexander 1977) and now wanted to make practical application and use of these techniques in the archeology and history projects at Choke Canyon. Thus our proposal to The University of Texas at San Antonio included the three major projects shown in Chart 2 (from the 1977 proposal). 


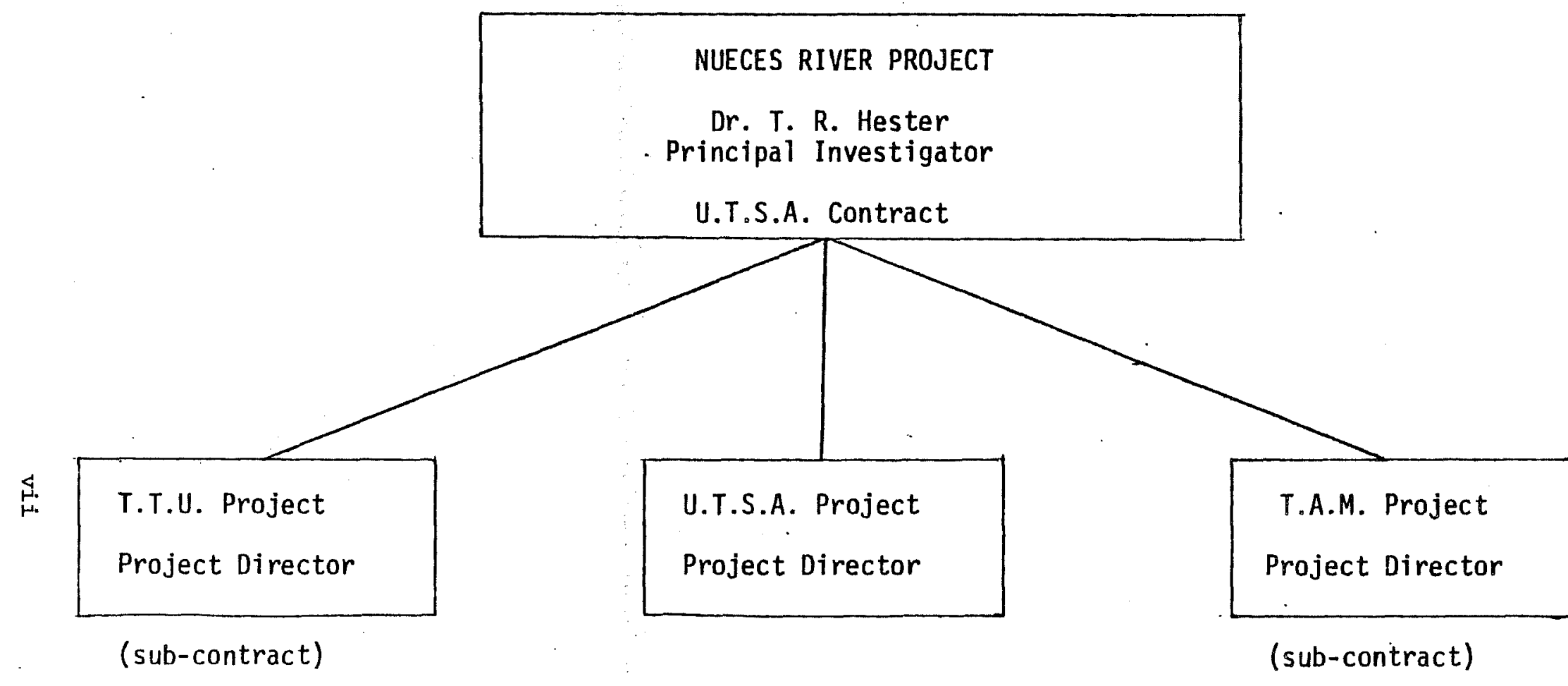

Chart 1. Project Organization. 


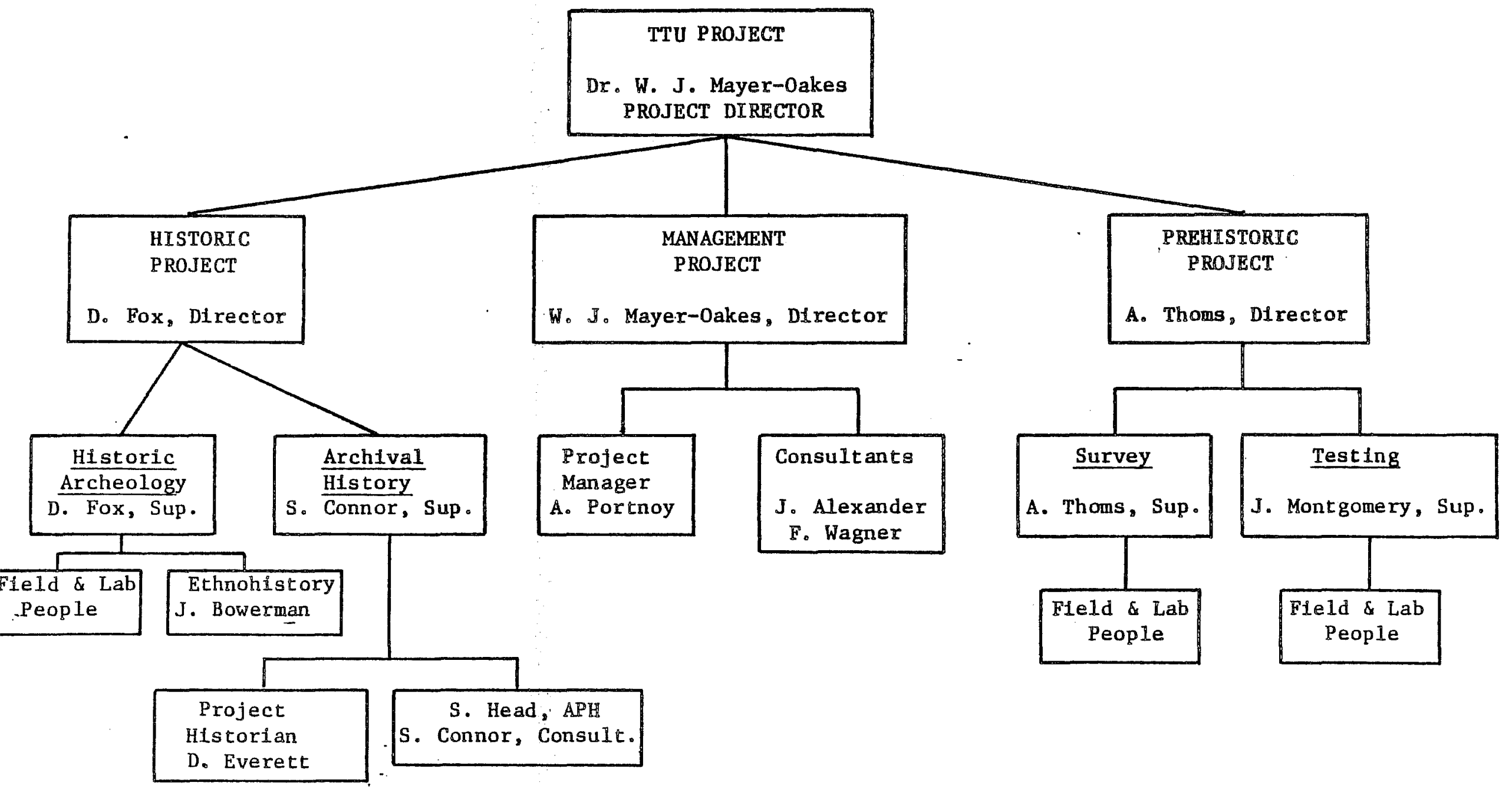

Chart 2. TTU Nueces River Project. 
Each of the three administrative project units was divided into action units with associated personnel and budget data, thus deriving a complex of five (5) working projects in management, history, ethnohistory, historic archeology, and prehistoric archeology. The proposal discussion of the management project included a preliminary plan and chart, showing in "milestone" fashion the various project stages, objectives and timing. This chart (Chart 3, presented as Figure 5 in the proposal) has already been published elsewhere (in Portnoy 1978). It is an adaptation of some of the concepts of Critical Path Methodology (CPM), with the fixed time schedule being a primary determinant utilized. Our idea in preparing it was to have an explicit schedule for use and revision by the management personnel as they helped the professional and technical specialists accomplish the total project in timely fashion.

Each of the five action units was defined and discussed in our proposal in terms of the following: pertinent project background data; research orientation (presented along with an explicit research design); a work schedule, including a list of people to be involved; and a budget. Our general attempt was to propose a high quality, but also a reasonable response to the Scope of Work. We first drafted ideal budgets and then revised these substantially downwards. Our total proposal budget came to 227,020 .

Subsequent negotiations between The University of Texas at San Antonio and the Bureau of Reclamation resulted in drastic changes in our proposed budget. We accepted, in late spring 1977, a subcontract with The University of Texas at San Antonio to carry out a reduced version of our proposal for a total of $\$ 75,845$. In the summer of 1977 field work commenced, and throughout the entire project we attempted to utilize and adapt where economically possible both the aims and the flavor of our proposed projects. The reduction in funds available eliminated completely two of the five proposed working projects (ethnohistory, management). Each of the three remaining projects was severely reduced--historic research by 66 percent, historic archeology by 57 percent, prehistoric archeology by 59 percent. Although the ethnohistoric project elimination was an important change, perhaps the most significant cut was the management project. Originally planned to be at about the 10 percent level (in terms of the whole project), it was completely eliminated. While we have no way of knowing how our explicit management project would have affected the total effort, I am convinced that many of the problems and difficulties encountered during the project would have been handled differently had there been a significant specific management effort set aside and explicitly available with personnel and budget support. As the project was carried out, we did utilize some people for specific management activities, but the largest part of the creative and intellectual activity of managing had to come from "after hours" effort of the project manager who was overloaded with "clerical" work. And, of course, the unpaid project director was also utilized for management purposes.

In the attached two technical reports that follow we present the results of the three projects, in which we aimed at $3-1 / 2$ of the original eight Bureau of Reclamation requirements (the ethnohistoric half of requirement 8 was not at tempted).

Dianna Everett was the project historian. She carried out the field work in collaboration with the historic archeology field project and worked under the 
supervision of Dr. Seymour Connor. Her report presents both basic oral and archival documentation as well as primary interpretation of these data.

The historic archeology project field work was carried out by Daniel Fox as planned, but he was unable to carry on with the laboratory analysis of data and report preparation, so it was necessary to arrange alternate staff for the post-field activities. Philip Bandy was able to pick up the threads of continuity for this project. He not only carried out the laboratory study and report preparation, but also spent a brief period in the field in order to check on questions raised in the lab. This field effort made substantive, if limited, additions of knowledge to that gained from the primary field work carried out by Fox and his crew. The lab study reported here constitutes basic documentation.

William J. Mayer-Oakes

Director of Cultural Resources Institute Texas Tech University 
Alexander, J. W.

1977 Management in Archeology: Scheduling Techniques Applied to Archeological Projects and Their Evaluation. Unpublished Master's thesis, Department of Anthropology, Texas Tech University.

Fox, D. and J. Alexander

1978 Business-like Archeology. In Scholars as Managers, edited by Alice W. Portnoy, Pp. 44-68. Interagency Archeological Services, Heritage Conservation and Recreation Service, Washington.

Mayer-Oakes, W. J.

1977 Proposal for Cultural Resources Investigation, Archeological and Historical, Phase I, Nueces River Project, Texas, in response to Bureau of Reclamation RFP 50-V0897. Cultural Resources Institute, Texas Tech University.

Montgomery, J. L.

1919 Site Testing Methodology, Choke Canyon Project. In Scholars as Contractors, edited by William J. Mayer-Oakes and Alice W. Portnoy, pp. 53-59. Interagency Archeological Services, Heritage Conservation and Recreation Service, Washington.

Portnoy, A. W.

1978 CRI research design and management techniques. In Scholars as Managers, edited by Alice W. Portnoy, pp. 94-99. Interagency Archeological Services, Heritage Conservation and Recreation Service, Washington.

\section{U.S. Bureau of Reclamation}

1977 RFP 50-V0897. Cultural Resource Investigations, Archeological and Historical, Phase I, Nueces River Project, Texas. Southwest Region, Amarillo. 
PART I

\author{
HISTORICAL RESOURCES OF THE \\ CHOKE CANYON RESERVOIR AREA IN \\ MCMULIEN AND LIVE OAK COUNTIES, TEXAS
}

By

Dianna Everett

Report of a project carried out by the Cultural Resources Institute

Texas Tech University 

For the past century and a half the history of the Choke Canyon Reservoir area has illustrated the evolution of an agricultural society into a technological society. In the mid-nineteenth century, settlement of the area began on the Frio River in the vicinity of Yarbrough Bend. Early settlers eked out a meagre subsistence by practicing a minimal amount of agriculture and by raising livestock. During the latter decades of the century the population slowly increased, spreading up and down the Frio River from Yarbrough Bend. By the turn of the century a small group of interrelated families was basing their subsistence on stockraising. Early in the twentieth century, however, oil and gas discoveries began to tie the area's residents to the world of technology. Today the people living in the reservoir area still occupy themselves by raising livestock; the mainstay of the economy, however, is the extraction of petroleum and natural gas. 


\section{ACKNOWLEDGMENTS}

Special thanks go to Dr. Seymour V. Connor, the project's historical consultant, for his advice and criticism; to the staff of the Southwest Collection of Texas Tech University for their assistance; to the investigators in locating unusual sources of information; and to the residents of Live Oak and McMullen Counties for their patience, cooperation and understanding. 
INTRODUCTION

This study is one part of a three-part subcontract between Texas Tech University and the University of Texas at San Antonio. The subcontract project was carried out between July 1, 1977 and September 1, 1978 by TTU's Cultural Resources Institute. As are the other two parts of the project (historic sites archeology and prehistoric survey), the historical research part is based on the Scope of Work requirements of Bureau of Reclamation RFP \#50-V0897 and the subsequent proposal and research design submitted to UTSA by CRI (Mayer-Oakes 1977).

This report fulfills the contract requirements for the investigation of the historical resources of the Choke Canyon Reservoir area in McMullen and Live Oak Counties, Texas (Fig. 1). The contract called for the reconstruction of settlement patterns, subsistence patterns, genealogy, and general history of the region. In addition, the contract required that the documentary research be coordinated with and oriented toward the archeological work being done on historic occupation sites in the reservoir area. Various procedures and methodological techniques were employed in complying with the contract requirements.

\section{Historical Approach}

The approach to the history of the Choke Canyon Reservoir area was initially conditioned by the scarcity of secondary printed material concerning the historical development of southwestern Texas (according to common historical usage, that portion of the state lying south of a line extending from Del Rio to Austin, and west of a line extending from Austin to Corpus Christi, is termed "southwestern Texas" and is so used in this report). Whereas local, county, and regional histories abound for the more populated areas of Texas, the southwestern portion has been virtually ignored by chroniclers of the state's history. Consequently, the re-creation of the history of the reservoir area was, for the most part, built upon a careful examination and analysis of primary documentary sources. The absence of printed materials and the subsequent reliance on documentary materials allowed the investigator to pursue an in-depth survey of specific settlement and subsistence patterns. This area-specific information, when combined with the data concerning the entire region, enabled the investigator to place the Choke Canyon area within the context of regional and state development. In the process, the characteristics of the smaller area became apparent. 


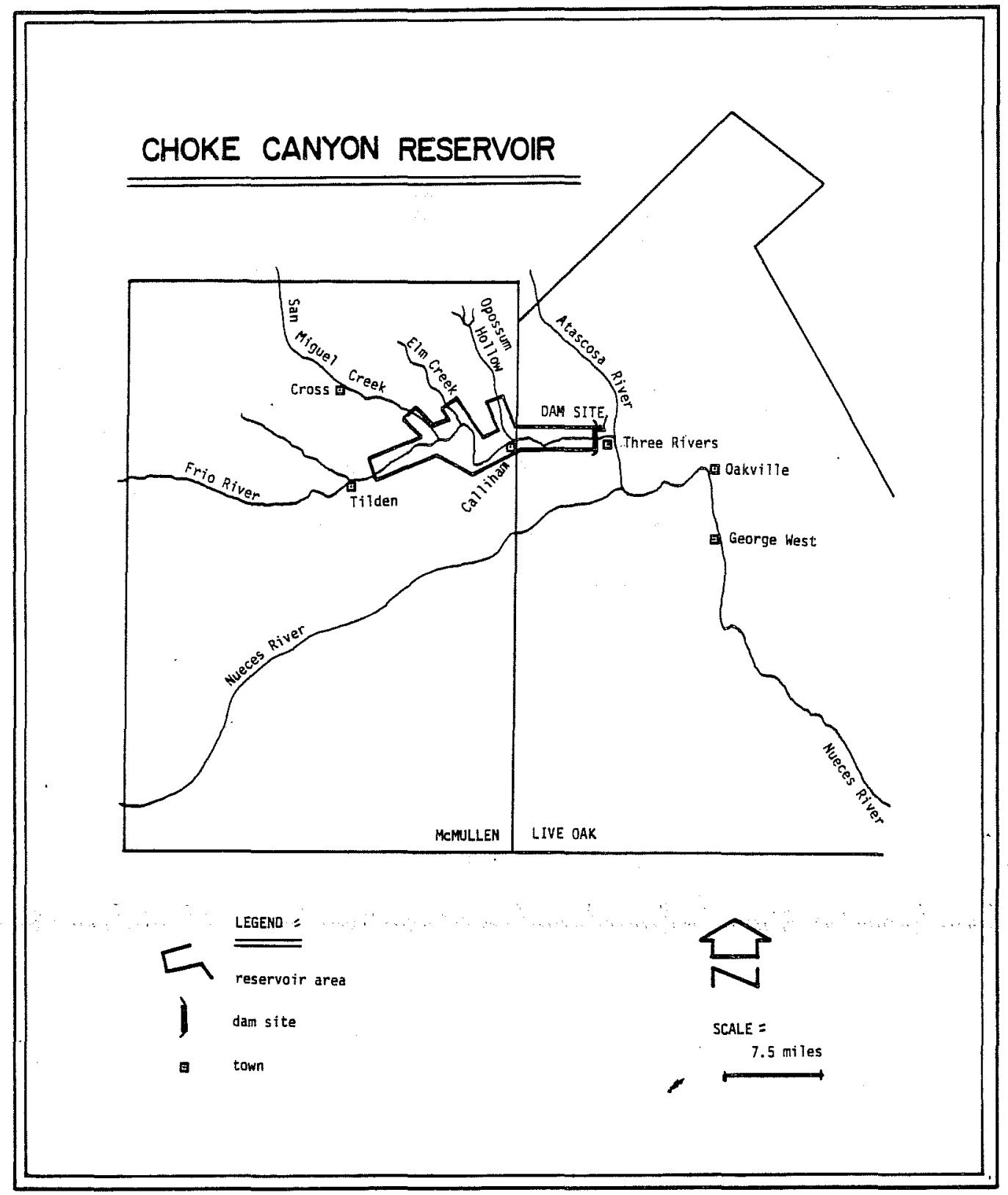

Figure 1. Choke Canyon Reservoir Area. 
Research Procedures

The research period, lasting from mid-July through late September in 1977, was divided into three phases: first, the preliminary. bibliographical and documentary search; second, the field research; and third, the statistical and documentary verification process. During the first phase, several weeks were devoted to ferreting out basic historical facts about the two-county area and its residents. This information was available in historical works, county histories, government documents, almanacs, and the like, and in the manuscript returns of the United States Censuses. From these sources, the patterns of settlement and subsistence could begin to be determined. All of these sources were available at Texas Tech University, in the University Library and in the Southwest Collection Historical Archive.

During the second phase, that of field research, four weeks were spent in the McMullen-Live Oak County area by the author, assisted by Stephen Head. These weeks were devoted primarily to gathering information on the historic archeological sites located in the reservoir area. The ownership history for each site was abstracted from county deed records, in an attempt to determine who may have constructed dwellings or buildings on the property. The owners' backgrounds were traced through birth, death, court, and other county records. Most of the sites were visited; in particular, the Byrne, Yarbrough Bend, Morgan and Snoga cemetery sites were carefully surveyed and all pertinent information recorded. Three other cemeteries in both counties were also examined and all pertinent information recorded; this procedure provided access to basic facts about the area's early residents. Finally, 14 local residents, many of whom were descended from the area's original settlers, were interviewed concerning their family histories and concerning the specific sites. The interviews, which were conducted in George West, Three Rivers, Calliham, Tilden, and San Antonio, were informal. Due to the age and hearing disabilities of most of the interviewees, the questions and comments were recorded by hand instead of on tape. In four cases, small groups of people were interviewed in "brainstorming" sessions designated to stimulate the memories of the participants. During the field research phase four meetings were held with the project's historical archeologist, Daniel Fox. During these sessions site data were exchanged and research procedures were discussed. In addition, the investigator gathered information from collections in libraries and museums in Tilden, Three Rivers, George West, Corpus Christi and San Antonio.

During the third research phase, that of statistical and documentary verification, the information collected during the two preceding phases was collated, checked for accuracy, and evaluated for comprehensiveness. In the process, any areas which might have been neglected were given due attention. The census materials were evaluated; 
site-specific information contained in the censuses was added to the other site data; and subsistence characteristics were abstracted from the census for each decade of the late nineteenth and early twentieth centuries. In addition, census information and biographical information were assembled for use in the genealogical study. Further research was then conducted in the archives of the University of Texas, the General Land Office, the Texas Historical Commission, the Texas State Library, and the San Antonio Public Library in order to discover the area's settlement patterns.

Report Preparation

The preparation of the Choke Canyon Reservoir Historic Resources Report was conducted in two phases. During the first phase, the month of October, the history of each historic archeological site was composed. While this was being done, new sites were discovered; an additional week of field research in McMullen and Live Oak Counties was required to fill in the data for these sites. In all, 28 historic archeological sites were researched and reported.

During the second phase, the month of November, the narrative history of the reservoir area was composed. Pertinent data gathered in the research phase were included to reflect patterns of settlement and subsistence. The most important data concerning settlement patterns proved to be that of the population censuses; the agricultural censuses provided invaluable data concerning subsistence patterns. The conclusions drawn from the census information were then supported by data from secondary printed sources and from other primary documentary sources. Written in chronological order, the report traces the development of the Choke Canyon Reservoir area, and the region in which it lies, from the early nineteenth through the late twentieth century. Within the historical narrative are interwoven specific descriptions of settlement patterns and processes, reconstructions of subsistence patterns and a genealogy of many of the original families in the area. 
HISTORICAL BACKGROUND

During the early decades of the nineteenth century southwestern Texas lay desolate and unpopulated. Few travelers explored the unrelieved monotony of its arid plains and brushy hills and river valleys. The area was only occasionally crossed by roving bands of Comanches and Apaches intent upon raiding the settlements farther to the east, along the Colorado River and near the coast, and by a few imperturbable merchants scurrying to and from San Antonio and Laredo by way of the Laredo Road. The region was devoid of natural resources; water, as scarce as other resources, was to be found in a few rivers and intermittent streams; the soil was rocky and infertile; and marauding tribesmen placed travelers in constant peril. These hindrances delayed the settlement of the area between and in the Atascosa, Frio and Nueces River valleys until mid-century.

Early Colonization Efforts

In the early 1820s the government of the Mexican state of Coahuila decided to create a fringe of settlement in southwestern Texas. In Texas, then a province of Coahuila, colonies had been established on the coast, along the Colorado River, and near Nacogdoches. These fledgling settlements needed protection from Indian raids. By promoting the organization of western colonies, the government could erect a buffer, placing the new colonists in harm's way but protecting the older settlements. According to the Mexican Constitution of 1824 and according to a colonization law passed in 1825 by the Coahuilan legislature, empressarial contracts were to be awarded to native and foreign gentlemen desiring to bring settlers into vacant Mexican lands. 1 By virtue of this statute any qualified individual could acquire an empressarial contract, under the terms of which he must introduce at least 100 families into a well-defined area within six years. In 1828 two Irish merchants residing in Matamoros, John McMullen and James McGloin, were awarded a contract granting them a large portion of southwestern Texas.

Empressarios McMullen and McGloin contracted to recruit 200 Irish families of good character, transport them from Ireland, and settle them in Texas. ${ }^{2}$ According to the contract, their colony was to be bounded by a line

- . beginning on the left bank of the river Nueces, at its intersection with the boundary line of the Ten Coastal Leagues of the Gulf of Mexico . . ., thence with said boundary line to a point ten leagues distant (southwardly) from the Presidio de La Bahia del Espiritu Santo (Goliad), thence on a straight line to the confluence of the river 
Medina, with the San Antonio, then with said river, on its right bank, to the point where it is crossed by the old road which leads from Bexar to the Presidio of Rio Grande, thence with said road to the river Nueces, and thence with said river downward on its left bank to place of beginning. 3

The grant included major portions of present Atascosa, Bee, Frio, LaSalle, Live Oak, and McMullen Counties and parts of present Bexar, Medina, San Patricio, and Wilson Counties. Within the grant each family was to receive 4428 acres. Each single man was to be given 1476 acres. In addition, each of the empressarios was to receive a premium of 23,000 acres for every 100 families introduced. 4 During the period of years between 1828 and 1834 McMullen and McGloin brought several shiploads of Irish families to Texas, but the empressarios failed to attract the requisite $200 .{ }^{5}$ Finally, in the summer of 1835, the Coahuilan government issued 84 land grant titles to the Irish colonists. 6 The grants lay within present San Patricio, Live Oak, and McMullen Counties.

Without exception, the Irishmen selected lands and surveyed their grants in the valleys of the Nueces, Frio and Atascosa Rivers. In present Live Oak County 15 grants were located along the right bank of the Nueces, 8 along both banks of the Frio, and 12 along both banks of the Atascosa. In present McMullen County two grants were situated along the right bank of the Nueces, and ten were placed along both banks of the Frio. The grants made along the Frio River extended from the confluence of that river with the Nueces, in Live Oak County, upstream for several miles into McMullen County. 7

Almost without exception, the Irishmen who selected land in this area declined to occupy their grants. The unsuitability of soil and climate deterred them. Most of the colonists remained in the towns of San Patricio and Corpus Christi, where protection from the elements and from the Indians was provided and where market services were available. A few of the Irish settlers moved into southeastern Live Oak County during the late 1830 s and early 1840 s. 9 None, however, moved into McMullen County. Although in 1836 the establishment of the Republic of Texas had opened the territory to unencumbered settlement, during the 1840 s and 1850 s the two areas remained largely unpopulated.

Exploration, $1842-1849$

Travelers and explorers journeying through southwestern Texas during the 1840 s commented on the wildness and emptiness of the area (Fig. 2). For example, in November and December of 1842, after an attack on San Antonio by Mexican General Adrian Woll, an expedition of volunteer militiamen led by Alexander Somervell pursued Woll southward along the Laredo Road toward Mexico. On the first day of December the Somervell expedition camped on San Miguel Creek, in present McMullen County. According to a diary kept by Sterling Brown 


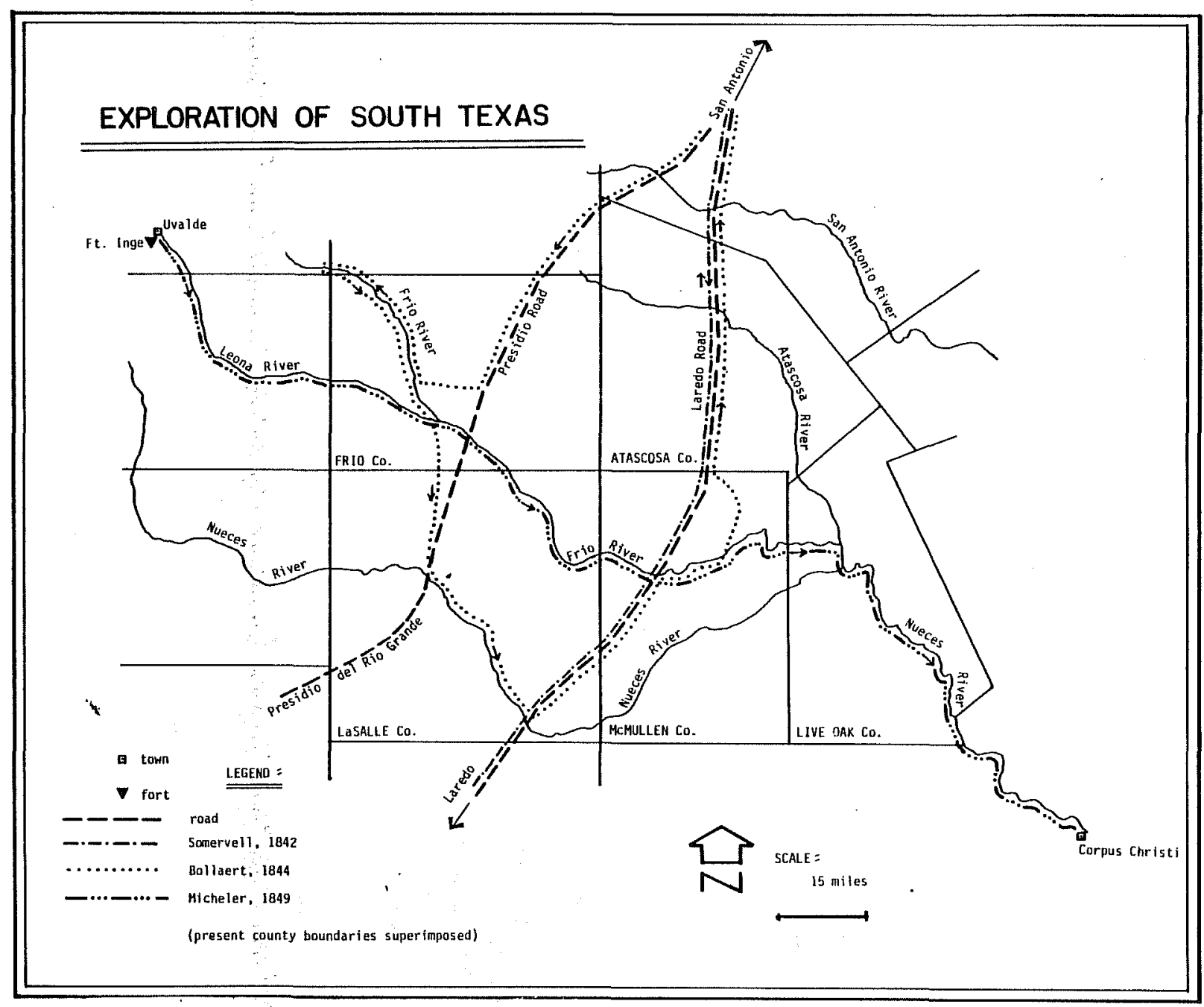

Figure 2. Exploration of South Texas. 
Hendricks, a meqker of the Texan force, no habitations were found along the road. Two years later, in 1844, William Bollaert, an English traveler and land speculator, toured the region. The Englishman was determined to investigate a land grant made in 1842 by the Republic of Texas to an English company. The 4,000,000 acre grant included much of present McMullen County, and Bollaert thoroughly explored the area between the Nueces and Frio Rivers (Fig. 2). He decried the lack of water and forage between the streams, but he indicated that good farm land was to be found along the rivers. He found no inhabitants, but he did encounter a group of escapees from a Laredo prison. 11 Several years later the United States Topographical Engineers comissioned Lieutenant Nathaniel Micheler to inspect the region lying between Fort Inge(near present Uvalde) and Corpus Christi. The officer was instructed to seek a route suitable for a military road joining the two points. During the summer of 1849 Micheler traveled from Fort Inge down the Leona, Frio, and Nueces Rivers. When he arrived in Corpus Christi, Micheler predicted that the route would never be used because of the absence of settlement between the fort and the coast. 12

Although Micheler's road was not built, an alternate route between San Antonio and Corpus Christi soon became operative. In late 1848 H. L. Kinney, a Corpus Christi resident, inaugurated a bimonthly freight and passenger service. The new cargo line followed the "San Patricio Trail" which had been used during the 1830s by Irish colonists traveling to San Antonio. The Irishmen had traveled along the Nueces River northward to the vicinity of present Oakville and then had proceeded due north to San Antonio. In 1845, during the War with Mexico, the path had been reopened by General Zachary Taylor, whose troops were stationed in southern Texas. ${ }^{13}$ The clearing of the road and the establishment of the freight line provided the developing frontier with a means of supply and communication.

During the 1840s the western edge of settlement in southwestern Texas reached a line almost congruent with the 98 th paralle1. 14 To the north were San Antonio and the new German and Alsatian settlements, New Braunfels, Fredericksburg and Castroville. To the south were Corpus Christi and San Patricio, on the coast, and Laredo, on the Rio Grande. Between these towns lay a vast, unoccupied region.

Urban Frontier

In southwestern Texas the frontier moved by means of organized urban migration. By the middle and late 1850 s settlers were beginning to move westward, establishing towns along the Nueces and Frio Rivers. The first settlers in Live Oak and McMullen Counties built towns; they seldom lived in isolation on farms and ranches. In this frontier area the creation of towns was, for a variety of reasons, absolutely necessary to insure the survival of the settlers. First, communities provided a small amount of protection from marauding Comanches. 
Second, the towns were important trade depots, serving as a means of entry into the market system of the region and as a means of acquiring the products of industry which the settlers could not provide for themselves. In so hostile an environment, in terms of soil and climate, all home industry must first be geared to minimal subsistence agriculture. Towns such as Gussettville, Oakville, and Tilden linked the frontier with the outside world and, in later days, made possible the growth of a ranching economy. Towns carried the frontier into McMullen and Live Oak Counties.

Gussettville, established in 1852, was the first town to arise on the frontier between San Antonio and Corpus Christi. The town's founder, John Fox, built a store and a dwelling on the Nueces River near the San Antonio stage road. South and east of the new town, where much of the land was cultivable, farmers began to settle with their families. 15 In 1853 the United States Army constructed Fort Merrill, on the Nueces sixty miles northwest of the coast, and Fort Ewell, on the Nueces at the crossing of the Laredo Road. The encampments provided the new settlers with a promise of security against Indian raids. 16 Then, in the late 1850 s, in response to the development of the area, the legislature of the State of Texas created Live Oak and McMullen Counties. 17 By this time settlement was moving rapidly northward along the Nueces River into central Live Oak County.

Oakville, the seat of the county, grew as a:planned community. In 1856 a large number of settlers met in Gussettville to organize a county government. Instead of naming Gussettville the county seat, the group decided to build a new town farther north. A local landowner donated a section of land for the townsite, and within the year Oakville was a lively trade center for the frontier. ${ }^{8}$ As the town grew, settlers began to move westward along the Frio River toward another new community, Tilden.

Tilden was the first community organized in McMullen County. In 1858 several families built "picket" houses in a bend of the Frio River at its junction with Leoncita Creek.19 A store was soon erected, and the town began to serve as a trade depot for an incipient ranching industry. 20 Several miles downstream, near a bend in the river, a second group of settlers built a cluster of "picket" houses and formed a community.

Yarbrough Bend, 1858 - 1880

In 1858, according to local tradition, pioneer families began to move into the area known as Yarbrough Bend. 21 The first to establish homes along the Frio included the families of John Swanson Yarbrough, a Dutch immigrant; Yarbrough's stepsons, James Tope and John Moore; Benjamin Franklin Winters, a veteran of the Somervell expedition; Peter Harrison, a carpenter; George A. Dilworth, a doctor; and Nathaniel and Joseph Walker, two brothers from Shelby County. 22 
By 1859 , eight residences had been constructed, and the Bend's population had risen to include 30 persons. During the next 20 years the community of dwellings grew slowly and consistently. By the late 1870 s the settlement extended along the south bank of the Frio River from a point near present Calliham westward to a point approximately five miles west of Tilden. At its peak the population of the community may have numbered as many as 30 interrelated and interdependent families. 23

A tentative geographical placement of the homes of several of the original settlers may be achieved through a careful examination of the United States Census rolls for 1870. By tracing the route of the census official as he enumerated dwellings and families in Live Oak and McMullen Counties and by documenting the location of key residences, the location of individual dwellings can be determined.

In July of 1870 the census enumerator, Robert Dempsey, traveled from southeastern Live Oak County northward into Oakville and then proceeded to follow the Frio River into McMullen County. His route may be traced by identifying families listed on the roll and by documenting their places of residence in 1870. Supporting evidence may be found in local histories, family records, county records, and other historical sources. That Dempsey began in the southeastern part of the county is demonstrated by the family names which he listed; most were Irish and were descendents of McMullen-McGloin colonists. Dempsey's arrival in Oakville was illustrated in a sudden profusion of merchants, businessmen, and county officials. Next, his progress up the Frio River was indicated by the presence of several prominent cattlemen who resided in the area in 1870.24

The enumerator was unsure of the location of the Live Oak-McMullen County line. He listed the dwellings of John Moore, Peter Harrison, and James Tope as the last in Live Oak County, and then he entered them as the first in McMullen County. Dempsey's duplicate entry was very significant, because these men were three of the five founders of the Yarbrough Bend community. Furthermore, they are designated as squatters. In the next dwelling lived Thomas Wright, the first individual designated as a landowner. ${ }^{25}$ In 1870 Wright owned and occupied a large tract of land situated three miles west of the county line. ${ }^{2}$ It may be deduced that the occupants of the preceding dwellings lived at the eastern edge of the Yarbrough Bend community. This suggests that the founding families -- Moore, Tope, Harrison, and Yarbrough -- may have settled in the eastern part of the river bend.

As he continued along the Frio River, Dempsey recorded the dwellings of George Dilworth, Charles Askins, and Francis Askins. Dilworth was an original settler in the Bend. Charles Askins was his son-in-law. These three dwellings lay in the center of Yarbrough Bend. The enumerator then proceeded northward along San Miguel Creek, recording the dwellings of James Franklin, Allen Franklin, John Hill, Sophronsa Taylor, and Samuel Bruce. Dempsey then entered the smal1 
village of San Miguel, located eight miles north of Tilden. There he found four families. Next he moved southward, returning to Yarbrough Bend, where he found Leonidas Wheeler's residence near the western edge of the community. Between Wheeler's house and the town of. Tilden, Dempsey found only one residence, that of James R. O'Neil. Judging from Dempsey's records, in 1870 nine families were living in the Yarbrough Bend community; those of John Moore, James Tope, Peter Harrison, Thomas Wright, George Dilworth, Charles Askins, Francis Askins, Leonidas Wheeler, and James $O^{\prime}$ Neil were all the enumerator discovered. Dempsey then proceeded into Tilden and listed its residents. Finally, he moved southward to the Nueces River and followed it into LaSalle County. 27

Tracing the enumerator's route during a given census year should yield a rough estimate of the location of the county's residents. However, a few hazards concomitant with this method must be noted. First, one must remember that census officials tended to record a person's name wherever he found the person, that is, at home or perhaps at a place of employment. Fortunately, this did not occur in the McMullen County census of 1870, and it occurred only once in the census of 1880 for the same county. Secondly, one must use the utmost care to discover other historical sources of documentation. Finally, one must adjust one's methodology to fit the area and the census under examination. The procedure used to examine McMullen and Live Oak Counties in 1870 and 1830 may not be suited to the study of another area. It may, however, serve as a model. The McMullen County censuses of 1870 and 1880 substantially corroborate the local tradition concerning the original settlers of Yarbrough Bend.

The founder of the community, John Swanson Yarbrough, was born in 1774 in Holland. He came to Texas in 1855, probably from Arkansas. 28 Yarbrough married three times and was twice widowed; his third wife, Frances, accompanied him into McMullen County in 1858. ${ }^{29}$ In 1862 Yarbrough was shot and killed in his own corral during an argument over a horse. He was buried in the Yarbrough Bend Cemetery. His wife died in 1868 and was buried beside her husband. 30 Yarbrough's stepsons, James Tope and John Moore, and his son, L. Dow Yarbrough, had accompanied their father westward. Each maintained a separate household in the community.

Yarbrough's stepsons and son resided on the Frio River at an undetermined point somewhere between the Live Oak County line and the mouth of San Miguel Creek. 31 By 1870 James Tope had married Selma Winters, daughter of another early settler in the Bend, and the couple were the parents of a two-year-old son. 32 A squatter, Tope made a moderate living as a stockraiser and farmer. His stepbrother, John Moore, had married Ellen Winters, sister of Selma Tope. 33 Moore's family included two small sons. As squatters, they raised sheep and cattle and farmed. 34 The two brothers remained in the same area until after 1880. Between 1870 and 1880 their stepbrother, L. Dow Yarbrough, established a residence upstream from the rest of 35 the family near his wife's father and brother, Headly and George White. 35 Yarbrough and the Whites rented 
land from Leonidas Wheeler, a prominent rancher, during the late 1870 s. The two families raised cattle and farmed. Moore, Tope, and Yarbrough were the last of the Yarbrough Bend residents to leave the community. 36

Benjamin Franklin Winters, Tope's and Moore's father-in-law, came into McMullen County in the early 1860s. 37 Winter's family were early Texas colonists, coming to the empressarial colony of James Vehlein in 1834.38 The entire Winters family, which included fourteen children, had come to Texas from Tennessee. James Winters, Benjamin's father, and James, Jr., and William, two of the brothers, participated in the Texas Revolution. 39 In 1842 James, Jr., and Benjamin traveled to Mexico with the Somervell Expedition. 40 According to family tradition, as they passed through McMulien County they vowed to return and settle there. 41 In 1846 the two brothers moved their families from eastern Texas into Live Oak County. They rented a farm on the Frio River several miles west of Oakville.42 By 1860 Benjamin Winter's family was expanding rapidly, and he decided to move westward into the Yarbrough Bend community. He remained in McMullen County until 1869.

In the late 1860s Peter Harrison, a carpenter born in Maryland, brought his family into the Yarbrough Bend community. A squatter, he raised stock and farmed. 43 At some time during the 1870 s the Harrisons moved from the eastern edge of the community to the Wheeler Ranch, where they lived with their son-in-law, George White. 44 Harrison's infant son, who died in 1868, was buried in the Byrne Ranch Cemetery. 45 His wife Amanda died during the 1880 s and was buried in the Yarbrough Bend Cemetery. 46

George A. Dilworth, McMullen County's first doctor, came to Texas with his family in 1836. He served in the war with Mexico from 1846 to 1848. In 1858 he moved his family to Yarbrough Bend. 47 During the 1860 s and 1870 s the doctor raised cattle and sheep along the Frio River. In 1877 he was appointed to serve as county judge, and in 1880 he moved into Tilden. 48 Dilworth and his wife are buried in the Byrne Ranch Cemetery in Yarbrough Bend. 49

Nathaniel H. Walker and Josseph C. Walker are reputed to have been original settlers of the Bend. However, neither was listed in the census of 1870 or 1880 for McMullen County. The brothers may have operated a ranch in the northeastern corner of the county, although neither owned property in the area. That they may have once lived in or near the Bend is substantiated only by the marriage of Joseph Walker in 1864 to Amanda Yarbrough, daughter of John Swanson Yarbrough, and by the burial of the couple's infant daughter in the Yarbrough Bend Cemetery.51

Most of the settlers residing in the Yarbrough Bend area during the $1860 \mathrm{~s}$ and $1870 \mathrm{~s}$ were squatters.52 It is difficult to determine why they persisted in living on land which they did not own. They may have assumed that the land belonged to the state and that they might eventually be able to acquire title to their small farms. Moreover, 
as the nearest branch of the General Land Office was located in San Patricio County, perhaps the squatters had neither access to nor knowledge of the appropriate means of applying for land titles. By 1860 all of the land in the Frio valley was under absentee ownership. 53 Most of the owners of the land were speculators who hoped to turn a profit as settlement spread westward. On the south side of the river, the Yarbrough Bend area was purchased in 1861 by Henry S. Foote, a former governor of Mississippi and in 1861 a member of the Congress of the Confederate States of America. 54 On the north side of the river the land belonged to William R. Hensley, deputy surveyor of the San Patricio Land District and to several San Antonio businessmen. 55 Foote retained control of his property until late in the 1870s. In 1877 he sold the land to Leonidas wheeler, a sheep rancher, who allowed the squatters to remain. 56 However, they gradually moved away. In 1882 Wheeler sold his ranch to Thomas O'Connor, a prominent rancher of Victoria County. 57 At this point the Yarbrough Bend community disappeared. $0^{\prime}$ Connor may well have evicted the last of the squatters.

Settlement and Subsistence, 1860-1870

During the 1860 s and 1870 s numerous families moved into Yarbrough Bend, yet the community remained unorganized. Incorporation was never attempted. No stores or other market facilities were established, although at some time around 1870 a small school was opened at the western edge of the community, near the point at which the TildenOakville Road crossed the Frio River. Typically, families of settlers moved in, remained for a few years, and then either acquired ranches elsewhere, moved into Tilden, or left the county entirely. The composition of the community was always fluid. 58

The members of the Yarbrough Bend community were not isolated from the outside world. On the contrary, they depended on nearby towns for market services. Most of the supplies for Tilden and Yarbrough Bend came through Oakville from San Antonio and Corpus Christi, the two regional distribution centers. 59 . The difficulties of transporting goods by oxcart or wagon from these towns precluded frequent buying expeditions. The few adornments found in the settlers' homes were obtained by means of infrequent trips to Tilden and Oakville and by means of annual supply trips to San Antonio and Corpus Christi. Items of clothing, hardgoods such as rifles, pistols, and lead for ammunition, and foodstuffs such as coffee, sugar, and flour, were obtained in this fashion. 60 The privations suffered by the settlers are reflected by the quality of their material possessions and by the methods of their subsistence.

The homes of the settlers on the southwestern Texas frontier were known as "picket" houses. The walls of these tiny dwellings were constructed of logs, or pickets, embedded vertically in the ground and plastered with mud. A square beam was placed on top of each wall of logs, and horizontal rafters were secured to the beams. Wooden pegs 
were used because of the scarcity of nails. The flat roof was covered with wooden shingles shaved from logs. Tables, chairs, and bed frames constructed of rough lumber served as basic household furnishings. 61 Few other adornments were visible.

For the most part the settlers living in Yarbrough Bend and near the towns were engaged in hunting and in minimal subsistence agriculture until well into the 1860s. They depended heavily upon wild game and wild cattle. Staple megts included fish, quail, deer, and wild turkeys, hogs, and cattle. 2 In addition, every year a group of settlers would plant a few small patches of corn, tend the crop in common, and share the harvest. They raised few other vegetable products. 63

During the late 1850 s and early 1860 s the primary means by which the frontiersmen entered the regional market system was by rounding up and selling wild cattle and mustangs. Many of these animals were strays from ranches situated to the south and to the north; others were descendants of Spanish livestock lost during the preceding centuries. Large herds of horses and cattle roamed the prairies of southwestern Texas. 64 The luxurious grass and mild climate provided an ideal habitat for the wild creatures. 65 The new settlers made good use of the opportunity to catch and sell the animals. The newcomers in Live Oak and McMullen Counties were among the progenitors of the cattle industry in southwestern Texas.

In the spring of each year many of the settlers would participate in communal "cow hunts," during which several men would spend a week or more rounding up wild cattle on the prairies and in the brushy valleys. The hunters usually took with them several "cow dogs" and a few tame steers called "work steers." The dogs were trained to trail the wild cattle, and the steers were used to gentle the captured bulls and cows. John Doak, who participated in several cow hunts in McMullen County during this time, described the method used to build a herd:

.... we took with us two work steers,..... and two other steers, which had been trained to lead wild steers.

We also took with us a couple of my dogs. . . As soon as we got our camp all settled we were ready to go to work. We would take the dogs out with us and when they would strike the trail of some cattle they stayed with it. . . . We stayed right behind the dogs and many times we got right up on the cattle before they ever knew anything about it. We always went out early of a morning and late of an evening to do the roping. These wild cattle did not go in big bunches, but every man would try to catch himself a cow each time we went out. When we... (would) rope one we would neck it to a tree with a two-strand twisted rawhide rope, or lariat, about ten feet long and which we called a "pial". This pial was short enough that the animal could not get twisted up in it and it was strong enough that they could not break it by setting back on it. After roping and tying up the cattle we would go back to camp and eat 
our dinner, if it was dinner time, and get one of the gentle steers for each wild cow we had caught; take it out to the tree where we had tied the wild one; neck the gentle one to him; turn them loose and drive them back to camp and corral them. After getting them in the corral we would un-neck the gentle steers and put them out to graze. The wild steers in the corral had to be fed so we burned the thorns off the prickly pear and fed them. After we got a good bunch gathered we would ride among them in the corral; drive them around and around with our gentle steers until they got used to us handling them. Then we could drive them out to graze with the gentle ones. When we had got enough cattle. . we quit and moved them to pasture. . .66

Finally, each man branded the cattle which he claimed to have caught.

Mustang hunts were also conducted as community affairs. However, mustangs were not roped and gentled as were the wild cattle. On the contrary, the risk of their breaking away was so great that another method was developed. Doak also described the most popular technique used in "mustanging":

We built a pen out of brush. We cut our posts ten feet long and set them in the ground, two posts side-byeach, about fifteen inches apart. Every four feet we set two more posts. Then we laid brush between the posts. About midway up on the posts we quit laying rope and zigzagged rope, clear around, and on top of that we put goodsized logs; then we piled more brush clear up to the top of the posts. This pen was a round one, about thirty feet in diameter. Then we built two wings, one wing being on a tangent with the circle pen; the other wing joined into the circle, about six feet from where the first wing touched the circle. In the space between the two, we made a gate. Having the pen circular, we knew that when we ran the mustangs through the gate, it would tend to make them go in a circle around the fence and they could not find the gate before someone could get there to close it. We built the wings of small posts and brush for one hundred fifty yards . . . When we stopped the wings they were about one hundred yards apart. 67

After capturing the steeds, each rancher branded his own, gathered them, and trained them to become saddle horses.

During the 1860s the market for wild cattle and mustangs was rather limited. Mustangs, when broken and trained, were salable in San Antonio and in eastern Texas. Cattle, on the other hand, were marketable only in New Orleans andin various coastal towns where meat-packing plants were located. ${ }^{6}$ Some herds could be sold locally, 
in Oakville, for transport to points father south. Interestingly, a local market was available for products derived from hogs. 69 Large herds of wild hogs inhabited this part of Texas. In the autumn of the year, many settlers would trap hogs in pens similar to the mustang pens. They butchered the hogs, dried the hides and the meat, and rendered the fat into lard. The hides, meat and lard were in demand in Oakville, Tilden, and San Antonio. In a good year a family might capture and dispose of a hundred hogs. The money derived from the hogs, horse, and cattle trade was used to finance the annual supply trips. 70

During the era of the Civil War, 1861-1865, the cattle industry in Live Oak and McMullen Counties became more organized and more lucrative. The war created a shortage of staples; a Union naval blockade of coastal towns curtailed the supply of flour, sugar, coffee, and articles of clothing formerly available in San Antonio and Corpus Christi. 71 The closing of the ports forced the cattlemen in southwestern Texas to look southward for a market. In 1862 settlers in McMullen, Live Oak and Atascosa Counties drove a large number of cattle into Mexico, where they traded the herds for supplies. At Laredo, for example, they purchased flour, sugar, clothing, yard goods, and other staples. 72 The experience gained on these initial drives was later to prove valuable.

After the war, with the opening of the coastal towns, buyers from the port cities came into McMullen and Live Oak Counties to purchase cattle. During the late 1860 s numerous herds were gathered and driven to the coast. 73 After 1867, however, the beginning of the northern drives gradually ended the coastal trade. In $186 \%$ the first herd of cattle was driven from McMullen County to Kansas. 74 Between 1868 and the turn of the century the cattle industry was the mainstay of the economy of southwestern Texas.

Between 1868 and 1884 the cattle-trailing industry reached its peak. During this era many large herds were driven to Kansas from McMullen and Live Oak Counties. Between 1872 and 1884 McMullen County ranchers sold over 50,000 head of stock to professional cattle buyers from Texas and Kansas. 75 Among the nationally prominent cattle contractors operating in the region were George W. West, who was a Live Oak County rancher; West's business manager, Dillard R. Fant, who was a major transportation agent; John 0. Dewees, of Wilson County; and the firm of W. D. Peck and Abner Evans, of Gonzales County, who maintained a commission house in Kansas City. ${ }^{76}$ The activities of the buyers stimulated the growth of the cattle industry. In turn, the maturation of the industry prompted the expansion of settlement in McMullen and western Live Oak Counties, where the climate and the topography attracted many ranchers.

In 1870 western Live Oak County was sparsely populated, and in McMullen County settlement was limited to the northeastern conner. The combined population of these two areas numbered approximately 400 . Half of the inhabitants lived in Tilden and Oakville. In their efforts to remain in communication with the outside world the settlers had created 
pockets of settlement near the towns. A few had ventured to settle along the Frio River and along Opossum Hollow, Elm Creek, and San Miguel Creek 77 (Fig. 3).

In terms of occupation and wealth, the social structure of the area was faintly revealed in the 1870 census. Of the 66 persons reporting occupations, 34 were classified as stockraisers, 16 as stockhands, 4 as farmers, 3 as merchants, and 9 as laborers. The majority of the population were employed in animal husbandry. In terms of wealth, livestock ownership and personal property valuations illustrate the division of the population into two segments. One third of the stockraisers seem to have been relatively prosperous. These owned 75 percent of the livestock. Their personal property valuations ranged between $\$ 5,000$ and $\$ 50,000$. Most of this third lived in the vicinity of Tilden. The estimated personal property valuations among the poorer stockmen ranged between $\$ 300$ and $\$ 3,000$. Most of these lived in the northeastern portion of the county, and almost half of them lived in and to the east of the Yarbrough Bend community. The river dwellers were the least prosperous in the area. In addition, the most prosperous were landowners, while many of the less fortunate were squatters. 78

Settlement and Subsistence, 1870-1890

Between 1870 and 1880 the settlement pattern and the social structure of the region began to change in response to the growth of the livestock industry. The expansion of the cattle, sheep, and wool markets after 1875 accelerated the changes. In order to enter the market the settlers needed to maintain moderately large herds on large blocks of land. Concomitant necessities were a hierarchy of employees and a systematized method of operation. During this era land first began to be purchased in great quantities by men who intended to become cattle raisers. These men and their families built homes far from the protection offered by towns and communities. The isolation of ranch life became the standard for southwestern Texas.

Typical of the large family ranches flourishing in the area during the 1870 s were those of Allen Franklin, John Hill, and James Lowe. Franklin and his brother James came to McMullen County early in the 1860s. Settling on San Miguel Creek, the brothers began to build a large herd by capturing wild cattle. By 1870 they owned several thousand head of cattle, which they soon sold. They used the proceeds of the sale to purchase several thousand acres in the northwestern portion of the county. 79 John Hill's 640 acre ranch was also situated on San Miguel Creek. In $1870 \mathrm{Hill}$ claimed to own $\$ 10,000$ worth of 1 ivestock. His cattle wandered on the open range because his ranch was too small to support a herd. ${ }^{\circ}$ South of Hill and the Franklins, in the vicinity of Tilden, lived the most prosperous rancher of the decade, James Lowe. Lowe, an original settler of Tilden, had begun his career as a cattleman in Atascosa County. 81 In 1858 he moved his entire family to the new settlement in McMullen County. He purchased a small ranch west of town, and by 1870 his herd numbered 10,000.82 Throughout the 1870s Lowe's operation was so large that most of the other ranchers in the area worked 


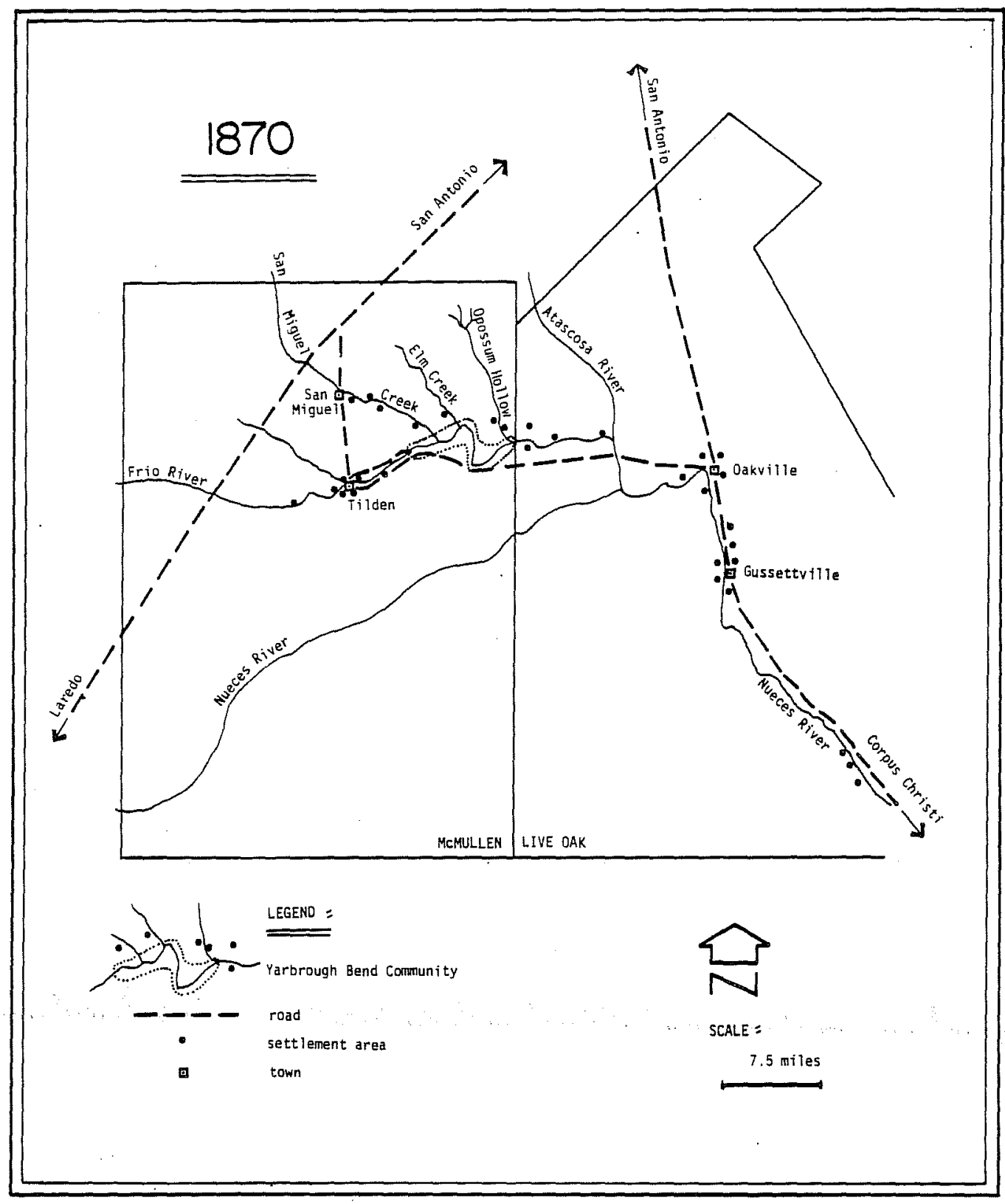

Figure 3. Project Area, 1870. 
for him during the spring roundups. At one time, Lowe's men reputedly branded 20,000 calves a year. 83 Because the range was not fenced, most of the ranchers grazed their cattle together in common pastures, separating their herds in the spring and readying them for the drives to Kansas.

By 1880 the number of ranches in the region had increased dramatically. In western Live Oak County, James and Mark Mahoney, brothers and descendants of Irish colonists, had established two 20,000 acre ranches along the Frio River. South of the Mahoney ranches lay the ranch of Sebastian Beall, a sheep raiser. In the adjoining area ranchers had begun to move into the uninhabited western and southern portions of McMullen County. Numerous ranches had been created along the Frio River west of Tilden, along San Miguel Creek northwest of Tilden, and along

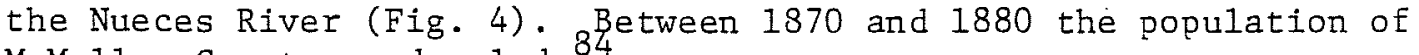
McMullen County quadrupled. 84

While the Census of 1880 did not record wealth valuations, it did reveal the occupational and demographic characteristics of the region. As in 1870, the majority were engaged in animal husbandry. Of the 300 individuals listing their occupations, 60 were classified as cattle raisers, 21 as sheep raisers, and 17 as raisers of both cattle and sheep. In addition, 25 persons were employed as stockhands, 85 as shepherds, and 28 as laborers on ranches. In all, over 200 individuals were engaged in animal husbandry. Most of the cattle raisers owned herds numbering fewer than 1000, and most of these ranchers lived northwest, west, and southwest of Tilden. Most of the sheep raisers owned herds numbering between 1000 and 8000 , and most of these ranchers lived east and southeast of Tilden, between the Frio and Nueces Rivers. Along the Frio River in Yarbrough Bend most of the land had been incorporated into large sheep ranches. All but three of the original settlers had moved, and those settlers, new and old, who remained were either employed as laborers on the ranches or rented property from the landowners. A few new squatters had moved in, but apparently even these worked for the sheepmen from time to time. 85

Although during the late nineteenth century most of the residents of southwestern Texas were engaged in raising cattle, many ventured into the sheep and wool industry. Ranchers began to introduce small herds of Merino sheep into the region during the Civil War.86 By the late 1870 s the wool market had improved, and some ranchers were obtaining large herds of Merinos from Mexico and devoting more effort to raising sheep than to raising cattle. 87 Between 1877 and 1883; the peak years for wool growers in Texas, 33 individuals registered sheep brands in McMullen County.88 Although cattle raisers were always more numerous than sheep raisers, the sheep population outstripped that of cattle. While the number of cattle in McMullen County rose from 3000 in 1870 to 8000 in. 1880 , the number of sheep rose from 5000 in 1870 to 40,000 in 1880.89 By 1882 the sheep population had increased to $80,000.90$ Most of the Merinos were maintained on the ranches and were sheared twice a year. The wool was sold to buyers from San Antonio. Nevertheless 


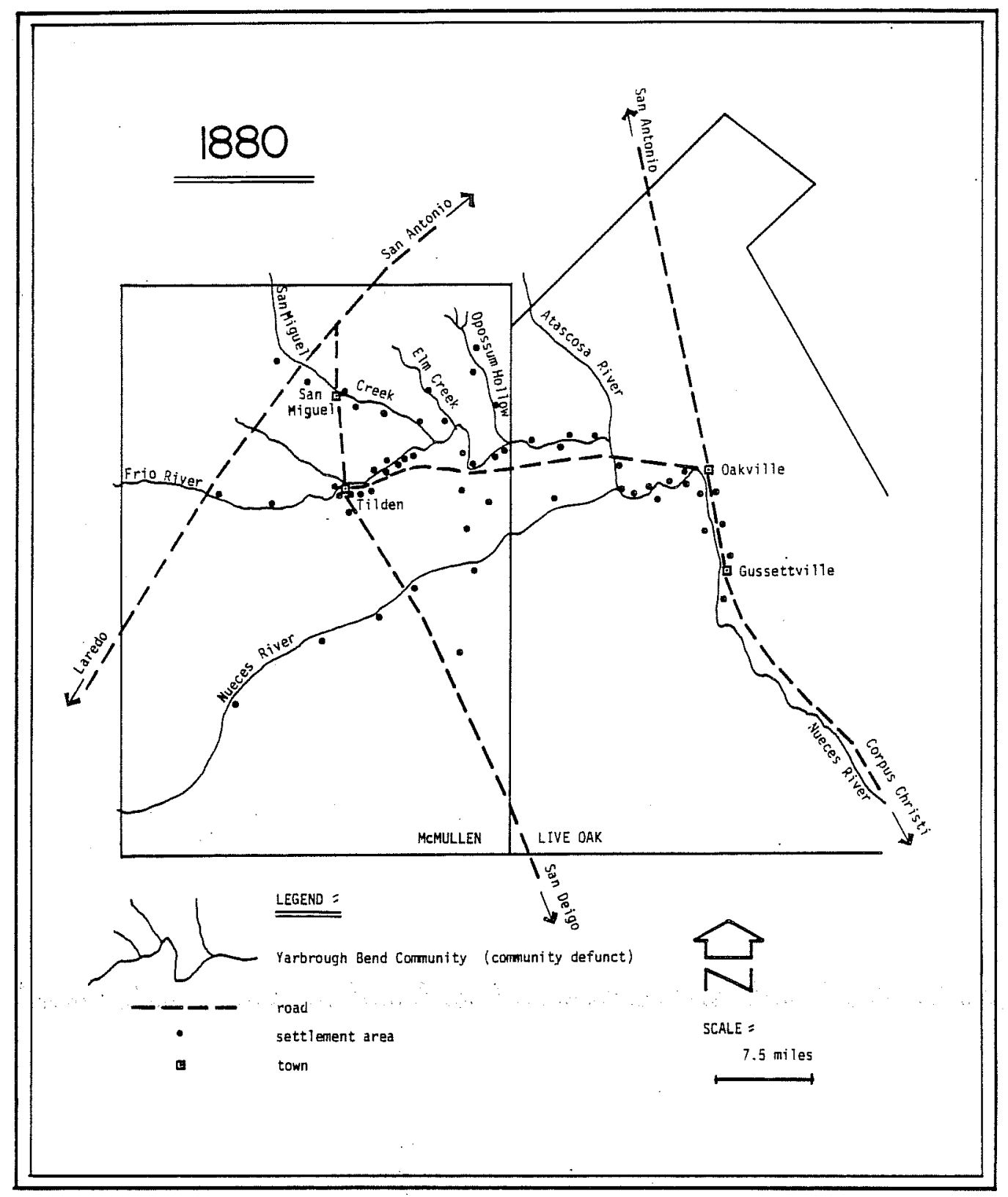

Figure 4. Project Area, 1880. 
sheep drives to the port cities of Indianola and Galveston were not uncommon.

The introduction of large-scale sheep ranching brought with it changes in the composition of society. Before the mid-1870s, the population of McMullen and western Live Oak Counties was relatively homogeneous. In terms of ethnic derivation and religious affiliation, residents were almost uniformly Anglo-Saxon and Protestant. A few Irish Catholics provided variety.

With the advent of the sheep and wool industry came an influx of Mexican immigrants, trained shepherds and shearers. Many of these were the pastores who had brought the first small bands of sheep from Mexico. Whereas cattle could be allowed to roam the range at will, tended occasionally by the rancher and his sons, sheep required constant supervision and care. Thus the Mexican pastor was in great demand; upon his skill depended the success of the venture. The shepherds brought their families with them from Mexico, and they also encouraged other Mexican shepherds and shearers to move to Texas. By 1880 the Mexicanborn population of McMullen and Live Oak Counties had risen to over 300.91 Of these, one-third were men employed as shepherds and shearers; two were independent goat raisers, and two were ambitious young wagoners who freighted supplies from Oakville to Tilden. None of the immigrants owned sheep, cattle, or horses. During the last four decades of the century most of the shepherds and shearers were Mexican immigrants and their descendants. 92 However, many young Anglo men served in the same capacities during the appropriate seasons. In essence, the sheep industry had helped to create a new class of agricultural laborers and had introduced into the area a new element of ethnicity.

The sheep population in southwestern Texas declined during the late 1880 s and early 1890 s.93 Although the market for wool remained stable, overgrazing of the land during the peak market years, 1881 and 1882 , reduced the amount of grass. As underbrush grew and replaced the grass, predatory animals proliferated. After a drought in 1886 and a harsh winter in 1886-1887, starvation and predators depleted the herds. 94 By 1887 sheep in the region numbered only 37,000.95 Large-scale sheep ranching was effectively ended. Until the discovery of petroleum at the turn of the century, cattle raising and farming were the primary economic factors in southwestern Texas.

Agriculture, however, was practically nonexistent in McMullen and western Live Oak Counties until the adaptation of the windmill to stock watering and irrigation. During the 1880s a few farmers living in the floodplains of the Frio and Nueces Rivers raised tiny crops of corn, sorghum, cotton, oats, hay, and potatoes. 96 While the soil in McMullen County was primarily rocky and infertile, in western Live Oak County farming could be profitable. By 1890 farmers were moving into the latter region and were raising crops of corn, broom corn, oats, rye, cotton, and sweet potatoes. 97 
The Twentieth Century

From time to time during the twentieth century new experimental varieties of plants have been introduced. For instance, during the second decade of the century numerous citrus trees were planted, but due to a severe drought the harvests were miniscule.98 Presently, few people are engaged in large-scale agriculture. Although rainfall has been generally sufficient, the soil is not rich enough. Agricultural pursuits have served the primary purposes of human subsistence and animal forage. During the present century the maintenance of a viable regional economy has been predicated upon the growth of the energy industry. Oil, gas, uranium, and lignite deposits are presently being developed.

In 1905 oil and natural gas exploration began in various locations along the Frio River.99 In the spring of 1908 a test water well situated on the Charles Byrne Ranch, in Yarbrough Bend, erupted; water and gas spurted over 100 feet into the air. The well's flow was not contained for five years. Then, in 1915, Byrne's son Edward found an oil seep in the bed of the Frio River. The Byrnes immediately contacted petroleum developer William M. Stephenson. As officers of the Grubstake Investment Association, Stephenson and his sons soon had 300,000 acres leased in McMullen County.100 The first gas well was opened east of present Calliham, on the J. T. Brown Ranch. In 1922 the first oil well was opened, on the J. T. Calliham Ranch.101 Calliham, an enterprising man, built a store near the well and hired several employees. Thus the town of Calliham came into being.

Within a few years the Grubstake Company had turned Calliham into a true boom town, replete with stores, cafes, "boarding houses," hotels, and a moonshiner appropriately named "Jitney Jake." Calliham grew, its population swelled by drillers and roughnecks living first in tents and then in rows of small "shotgun" houses. 102 Finally, in the mid-1920s, Stephenson installed a water system and gas street lights.

During the 1920s the number and size of the gas and oil fields grew as drilling proceeded. In 1923 a pipeline was constructed to transport oil from the Calliham field to a refinery in Three Rivers, 25 miles to the east. In the same year a gas pipeline was constructed to supply San Antonio with its first natural gas.103 Although the Calliham field declined in importance during the 1930s, by 1939 many oil fields had been opened in both counties, and more were developed during the next four decades.104

During the 1960s and 1970 s uranium and lignite mines have been developed in both Live Oak and McMullen Counties. Uranium mining is a major source of income in Live Oak County, while in the adjoining county, strip mining operations have recently begun along San Miguel Creek. Both industries provide the area with economic support, although the majority of the population do not partake of the profits. Most people living in the region are still as deeply involved with the ranching industry as were their pioneer forefathers. 
Genealogy

Today the residents of western Live Oak and McMullen Counties form a closely-knit group. In a sense, they display some characteristics of what might be termed "amoral familism" in their sense of group identity and in their opposition to newcomers. Many of the pioneer families of these counties intermarried during the $1870 \mathrm{~s}$ and $1880 \mathrm{~s}$. Furthermore, during the 1870s several groups of families, such as the Teals, Byrnes, Wheelers, and Martins, moved into the area from Shelby and Refugio Counties, where the families were already intertwined by marriage. During their residence in southwestern Texas several generations of these families have become even more closely united. In fact, the unraveling of some of the intricate family relationships in McMullen County, for instance, proved to be a challenging pursuit.

Information gleaned from interviews with assorted McMullen County residents gave the definite impression that most are related. Working under this assumption, three presumably unrelated individuals were selected and consulted concerning their family backgrounds. Then a genealogical table was constructed for each. The three were William Kuykendal.1, a rancher; Clifton Wheeler, a rancher; and Mary Ruth Teal Franklin, a county official.105 The following chart (Table 1) indicates the interrelationship of six generations of residents.

The Kuykendall family came into McMullen County in the late 1870s. Descendants of Austin colonists, the Kuykendalls had lived in Texas since the 1820s. 106 Upon arriving in southwestern Texas many of the male members of the family entered the ranching industry, raising sheep and cattle for the next 100 years. They gradually acquired several large ranches in the western part of the county. William Kuykendall is a great-grandson of both Abner Kuykendall, an Austin colonist, and Thomas King Byrne.

In 1880 the family of Charles Byrne moved from Refugio County to McMullen County. Byrne was the son of Thomas King Byrne, an Irishman who emigrated to Texas iff the 1830 s and settled in the Power and Hewetson colony near the coast. ${ }^{10}$ He was also the nephew of James Byrnes, one of the founders of the town of Lamar. While in Refugio County, the Byrnes family lived in close association with the Teal family and the Martin family. 108 Upon coming to McMullen County, Charles Byrne purchased a large ranch in the eastern part of Yarbrough Bend. Byrne's wife was a daughter of John Teal.

In 1879 the family of John Teal moved from Refugio County to. McMullen County. Teal's brother Peter had been a Power and Hewetson colonist, but the family had lost all of its property in Refugio County by 1870.109 John Teal purchased a tract of land in McMullen County from one of his Refugio neighbors, John Martin. Bringing his.family westward, Teal settled on the Frio River at the western edge of the Yarbrough community. Over the next 10 years he acquired most of the land on the north side of the river across from the Bend. His daughter, Mary, who was married to a Martin, lived with her parents on their ranch. 
The Martin family moved into McMullen County from Refugio County during the late 1870s. Zachariah Martin, the first of his family to reside in Texas, was a cousin of John Teal.110 The Martins, Teals, and Byrnes all moved westward together. During the nineteenth and twentieth centuries several members of the Martin family have served as county officials. Most have resided in Tilden, although several have owned and leased ranch property in the county.

The Horton, Henry and Snowden families came to McMullen County in the 1880s. Eck Horton and his brothers and nephews gradualiy acquired a large ranch at the western edge of Yarbrough Bend, on the south side of the river. L. W. Snowden came into McMullen County and opened a retail store in Tilden.11l During the 1880 s and 1890 s he acquired ranching interests, and in the early 1900s he bought a ranch on the north side of the river at the eastern edge of the Yarbrough Bend community. The family of Frank L. Henry came to McMullen County from Refugio County. 112 Henry was a descendant of Irish colonists. During the late nineteenth and early twentieth centuries the Henry family have operated large ranches in northern and central McMullen County.

The family of Leonidas Wheeler, a prominent McMullen County rancher, came westward from Shelby County in 1869. Wheeler married a member of the Walker family, also of Shelby and later of McMullen County. During the 1870s Wheeler owned the entire Yarbrough Bend area. His son, William $R$. Wheeler, was also engaged in the cattle industry. Clifton Wheeler is a grandson of Leonidas Wheeler. 113

The family of Ralph Franklin were pioneer McMullen County residents. The Franklin brothers, James and Allen, moved from Atascosa County to McMullen County early in the 1860s. During the next few decades they established extensive ranching interests. Ralph Franklin was a son of Allen Franklin. During the 1890 s and around the turn of the century, Ralph Franklin's Ranch was one of the largest and most prosperous in the county. Franklin's son, Sam, married Mary Ruth Teal, a granddaughter of John Tea1. 114

The Holland family were original settlers of Tilden. In 1858 Green Holland and his sons, Sam, Rufe, and John, moved from Atascosa County and helped establish the first town in the new county. The Hollands resided in Tilden for several decades, although several of them moved to San Miguel during the 1870s. Minerva Holland, daughter of Green Holland married Ralph Franklin. 115

As the genealogical chart for these families was constructed it became apparent that the families of the three individuals under examination were related either by blood or by marriage to the other families. For instance, the Wheeler family is connected by marriage to the Walker, Yarbrough, Kuykendall, Martin, Teal and Byrne families. The Teal family is related by marriage to the Kuykendall and Byrne families and by blood to the Martin family. The families appearing in this chart represent onethird of the total number of extended family groups presently residing 
in the county. The population of the area has numbered approximately 1000 since the 1880s. Among such a small, relatively isolated, and exclusive group, frequent intermarriage is not surprising. Further study would no doubt reveal interesting methods of mate selection and kinship reckoning.

Summary

The area in and between the Atascosa, Frio and Nueces river valleys was not settled until the mid-nineteenth century. Climate and soils unsuitable for agriculture had discouraged earlier settlers, including those brought in by McMullen and McGloin. Settlers started to move westward from other parts of Texas in the $1850 \mathrm{~s}$, establishing small towns and communities along the Nueces and Frio Rivers. Gussettville and Oakville were established in Live Oak County, then Tilden in McMullen County. The Yarbrough Bend community then grew up between Oakville and Tilden. Many of these early settlers were squatters and this situation prevailed into the 1880 s.

During the 1850 s and 1860 s, the settlers in this area made great use of wild game and cattle and engaged in raising small, communal crops of corn. For cash to buy other supplies, they rounded up and sold wild cattle and mustangs and caught and processed wild hogs for marketable pork products. Most of their supplies came through Oakville from San Antonio and Corpus Christi, although during the Civil War period they found it necessary to make some supply trips to Mexico.

During the 1870s, cattle-trailing became more important, first to the coastal towns, and later for the northern drives to Kansas. Large cattle ranches began to develop, with families living on the ranches themselves instead of in established towns and communities. The number and size of ranches continued to grow into the $1880 \mathrm{~s}$. The range was open and the herds were separated in the spring for the drives north.

The 1870 s also saw the rise of a sheep and wool industry. This introduced a growing number of Mexican immigrants who were employed as shepherds and shearers. Most of the wool was sheared and shipped from the ranches, but there were some sheep drives to coastal towns. Large-scale sheep ranching ended by 1890 . The land had been overgrazed, brush and predators had proliferated, summers were dry and winters harsh. Agriculture became more important in the $1890 \mathrm{~s}$, but cattle raising was the most important economic activity.

Oil and gas discoveries were made in the 1900 s and these resources were intensively developed during the 1920s. This has continued until the present time. Uranium and lignite have been mined since the 1960s. While these mineral resources are important to the area economy, most inhabitants are still engaged in one aspect or another of the cattle ranching industry. 
The portions of McMullen County and Live Oak County which are about to be inundated are rich in frontier history. When, in the $1850 \mathrm{~s}$, the Texas frontier had barely advanced to the timber line, settlers, were carving out homes in a hostile environment along the Frio River. Their lives were made somewhat easier by the existence of two towns, Oakville and Tilden, at either end of the river settlement. For the last half of the nineteenth century and for the first seven decades of the twentieth century, the early settlers and their descendants have wrestled a meagre living from the land. By means of ranching and subsistence agriculture, they have prospered in an area unfriendly to man and beast alike. The small population of the area today further attests to the undesirability of living there. Despite hazards and hindrances, the pioneers participated in the birth of the cattle industry in southwestern Texas and in the United States in general. Many of them drove cattle to Kansas; some of them were and are among the most prominent cattlemen in the nation. Furthermore, the region witnessed one of the earliest oil discoveries in Texas, following the initial east Texas discoveries by only six years. In the future, the region and its people will no doubt play a valuable role in the uranium and lignite industries. In sum, the story of the Live Oak and McMullen County pioneers is a tribute to the human will to survive. 
Notes

1. H.P.N. Gamme11, Laws of Texas, 1823-1897. (Austin: Gamme11 Book Co., 18.98), Vo1. I, P. 40 .

2. Record of Translations of Empressario Contracts (Ms. volume, Spanish Archive, Archives Division, General Land Office, Austin, Texas).

3. Ibid.

4. Ibid.

5. William H. Oberste, Texas Irish Empressarios and Their Colonies

(Austin: Von Boeckmann-Jones Co., 1953), p. 138.

6. Original Titles to Lands Granted in McMullen and McGloin's Colony (Spanish Archive, Archives Division, General Land Office, Austin, Texas), Vols. LIX - LX.

7. Map of Live Oak County (Austin: General Land Office, 1959); Map of McMullen County (Austin: General Land Office, 1876); Abstracts of All Original Texas Land Titles (Austin: General Land Office, 1942), IV, PP. 623,688 .

8. Oberste, pp. 59-63.

9. Live Oak County Centennial (George West, Texas: The Press of the Enterprise, 1956), n.P.

10. Sterling Brown Hendricks, "The Somervel1 Expedition to the Rio Grande; 1842," Southwestern Historical Quarterly, 23(1919), pp. 121, 139.

11. Eugene W. Hollon and Ruth L. Butler, eds., William Bollaert's Texas

(Norman: University of Oklahoma Press, 1956), pp. 351-370.

12. A. B. Bender, "Opening Routes Across West Texas, 1848-1850,"

Southwestern Historical Quarterly, 37(1933), pp. 130-131.

13. Robert H. Thonhoff, San Antonio Stage Lines, 1847-1881 (E1 Paso:

Texas Western Press, 1971), p. 7.

14. Seymour V. Connor, Texas, A History (New York: Thomas Y. Crowell Company, 1971), p. 170.

15. Historical Marker Files, Live Oak County (Texas Historical Commission, Austin, Texas). 
16. Robert M. Utley, Frontiersmen in Blue: The United States Army and the Indian, 1848-1865 (New York: Macmillan Co., 1967), p. 71.

17. Live Oak County Centennial, n.p.

18. Thelma Linholm, "History of Oakville" (Unpublished Master's Thesis, Texas A \& I University, 1950), pp. 11-17.

19. Historical Marker Files, McMullen County (Texas Historical Commission, Austin, Texas.)

20. Joseph Pate Smyer, "A History of McMullen County" (Unpublished Master's Thesis, University of Texas, 1952), pp. 48-51.

21. Mary Kuykendal1 May and Florine Winters Zavisch, "Yarbrough Bend," Historical Marker Files, McMullen County (Texas Historical Commission, Austin, Texas), n.p.

22. Ibid.

23. Ibid.

24. United States Ninth Census, 1870 (Returns of Schedule One, Population, for McMullen County, Texas.) (Census returns here and in all subsequent notations are from microfilms in the Southwest Collection, Lubbock, Texas.)

25. United States Ninth Census, 1870 (Returns of Schedule One, Population, for McMullen County, Texas.)

26. McMullen County, Texas, Deed Records, Vol. A, p. 98.

27. United States Ninth Census, 1870 (Returns of Schedule One, Population, for McMullen County, Texas. Returns of Schedule Two, Agriculture, for McMullen County, Texas.)

28. Smyer, p. 248 .

29. Gladys Ritter to Dianna Everett, interview, August 15, 1977, Tilden, Texas. Mrs. Ritter is a descendant of John S. Yarbrough.

30. Ibid.

31. United States Ninth Census, 1870 (Schedule One, Population; Schedule Two, Agriculture).

32. May and Zavisch, n.p.

33. Ibid.

34. United States Ninth Census, 1870 (Schedule One, Population; Schedule Two, Agriculture).

35. Ibid. 
36. May and Zavisch, n.p.

37. May and Zavisch, n.p.

38. Sam Houston Dixon and Louise Wiltz Kemp, The Heroes of San Jacinto

(Houston: Anson Jones Press, 1932), pp. 361-362.

39. Dixon and Kemp, p. 362; A. J. Sowe11, Early Settlers and Indian

Fighters of Southwest Texas (Austin: B.C. Jones and Co., Printers, 1900), pp. 39-41.

40. Joseph M. Nance, Attack and Counterattack: the Texas-Mexican Frontier, 1842 (Austin: University of Texas Press, 1964), p. 647.

41. "McMullen County Historical Essays," McMullen County Historical

Association (Mss. in McMullen County Museum, Tilden, Texas).

42. United States Eighth Census, 1860 (Returns of Schedule One, Population, for Live Oak County, Texas.)

43. United States Ninth Census, 1870 (Schedule One, Population; Schedule Two, Agriculture); May and Zavisch, n.p.

44. United States Tenth Census, 1880 (Schedule One, Population; Schedule Two, Agriculture, for McMullen County, Texas.)

45. Personal observation by the author, August 11, 1977.

46. Gladys Ritter, August, 1977.

47. May and Zavisch, n.p.

48. McMullen County, Texas, Commissioners' Court Minutes, 1877-1900.

49. Personal observation by the author, August 11, 1977.

50. May and Zavisch, n.p.

51. Gladys Ritter, August, 1977.

52. United States Ninth Census, 1870 (Schedule One, Population; Schedule Two, Agriculture.)

53. Abstracts, IV, pp. 688-714; Map of McMullen County (1876).

54. Ibid.

55. Ibid.

56. Clifton Wheeler to Dianna Everett, interview, October 14, 1977 , Tilden, Texas. 
57. Ibid.

58. Smyer, p. 57.

59. Ibid., p. 54.

60. R. J. Lauderdale and J. A. Doak. Life on the Range and on the Trail

(San Antonio: Naylor, 1936), Pp. 1-5.

61. May and Zavisch, n.p.

62. Lauderdale and Doak, pp. 1-11.

63. Charles Walker to Dianna Everett, interview, August 10, 1977, Tilden, Texas.

64. J. Frank Dobie, A Vaquero of the Brush Country (Dallas: The Southwest Press, 1929), pp. 218-219.

65. Edward Everett Dale, The Range Cattle Industry (Norman: University of Ok1ahoma Press, 1930), p. 116.

66. Lauderdale and Doak, pp. 11-13.

67. Ibid., pp. 37-38.

68. Nalter Prescott Webb, The Great Plains (Boston: Ginn and Company, 1931), p. 211.

69. Dale, p. 24.

70. Lauderdale and Doak, pp. 2-4.

71. Ibid.

72. Connor, pp - 198-199.

73. Smyer, p. 80 .

74. Webb, pp. 207-216.

75. Smyer, p. 80 ; Lauderdale and Doak, p. 8.

76. McMullen County, Texas, Record of Marks and Brands, 1870-1890.

77. Ibid.; Jimmy Skaggs, The Cattle-Trailing Industry Between Supply and Demand, 1868-1890 (Lawrence, Kansas: The University Press of Kansas, 1973), Pp. $11,63,65,80,81$.

78. United States Ninth Census, 1870 (Schedule One, Population; Schedule Two, Agriculture).

79. Ibid. 
80. Ralph S. Franklin, The New Encyclopedia of Texas, ed. Ellis A. Davis (Dallas: Texas Development Bureau, 1927), III, p. 1995.

81. United States Ninth Census, 1870 (Schedule One, Population; Schedule Two, Agriculture).

82. W. A. Lowe, A Twentieth Century History of Southwest Texas, ed. D. H. Hardy (New York: Lewis Publishing Co., 1907), p. 474.

83. Dobie, p. 218 .

84. United States Tenth Census, 1880 (Returns of Schedule One, Population, for McMullen County, Texas; Returns of Schedule One, Population, for Live Oak County, Texas; Returns of Schedule Two, Agriculture, for McMullen County, Texas; Returns of Schedule Two, Agriculture, for Live Oak County, Texas.)

85. Ibid.

86. V. W. Lehman, Forgotten Legions: Sheep in the Rio Grande Plain of Texas (E1 Paso: Texas Western Press, 1969), p. 24; Edward N. Wentworth, America's Sheep Trails (Ames, Iowa: Iowa State College Press, 1948), pp. 382-383.

87. McMullen County, Texas, Record of Marks and Brands, 1870-1890.

88. Ibid.

89. Compendium of the Eighth Census, 1870 (Washington: Government Printing Office, $18 \overline{72)}, \overline{p .802}$; Compendium of the Ninth Census, 1880 (Washington: Government Printing Office, 1884 ), p. $910-911$.

90. Resources, Soil and Climate of Texas, Texas Department of Agriculture, Insurance, and Statistics (Galveston: A. H. Belo and Co., 1882), p. 216.

91. United States Ninth Census, 1880 (Schedule One, Population, for McMullen County; Schedule One, Population, for Live Oak County; Schedule Two, Agriculture, for McMullen County; Schedule two, Agriculture, for Live Oak County).

92. Ibid.

93. Francis W. Johnson, A History of Texas and Texans, ed. E. C. Barker and E. W. Winkler (Chicago: American Historical Society, 1914), P. 623.

94. Smyer, p. 140; Clifton Wheeler, August, 1977.

95. First Annual Report of the Agricultural Bureau, 1887-1888, Department of Agriculture, Insurance, and Statistics (Austin: State Printing Office, 1889), p. 155 . 
96. Second Annual Report of the Agricultural Bureau, 1888-1889, Department of Agriculture, Insurance, and Statistics (Austin: State Printing Office, 1890), PP. 160, 174 .

97. Ninth Annual Report of the Agricultural Bureau, n.d., Department of Agriculture, Insurance, and Statistics (Austin: Jones and Co., 1897), p. 169.

98. Yearbook, 1909, Department of Agriculture (Austin: Von BoeckmannJones, 1910), p. 575 .

99. C. A. Warner, Texas Oil and Gas Since 1543 (Houston: Gulf Publishing Co., 1939), p. 52 .

100. Pleasanton Express, October 26, 1966.

101. Ibid.

102. Ibid.; Ott Reagan to Stephen Head, August 4, 1977, Calliham, Texas.

103. Warner, pp. 123-125.

104. Ibid., p. 306.

105. Mary Ruth Teal Franklin to Dianna Everett, interview, October 13, 1977; William Kuykendall to Dianna Everett and Stephen Head, interview, August 9, 1977; Clifton Wheeler to Dianna Everett, interview, October $14,1977$.

106. Worth S. Ray, Austin Colony Pioneers (Austin: privately published, 1949), p. 40.

107. Jamie Byrne, A Short History of the Byrne Family (privately published, 1950), n.p.

108. Mary Ruth Franklin, October, 1977.

109. Ibid.

110. Millard F. Martin, Zachariah Martin, 1790-1873 (privately published, 1976), P. 600 .

111. Gladys Snowden Wheeler, October, 1977.

112. Smyer, p. 227.

113. Clifton Wheeler, October, 1977.

114. Mary Ruth Franklin, October, 1977; Smyer, p. 223, Historical Marker Files (Texas Historical Commission, Austin, Texas).

115. Smyer, pp. 229-230. 
LIVE OAK COUNTY ARCHEOLOGICAL SITE HISTORIES *

\section{Site 4ILK66 (Nichols House)}

Located on the Nichols Ranch, 50' east of the Frio River, 150' west of the Choke Canyon dam site, the Nichols house site comprises a stone foundation and chimney, an associated cistern and refuse accumulation, and debris of outbuildings. This substantial complex lies within the boundaries of a 4605 acre tract granted in 1835 by the Republic of Mexico to Simon Ryan, a McMullen-McGloin colonist.

In 1836 Ryan sold the land to James McGloin, of San Patricio, who held the tract until 1840. In that year Edward W. Sanders, of Matagorda County, purchased the land. In 1845 Sanders sold the property to Richard Blossman, of Calhoun County. 1 Until 1858 the Ryan grant had no resident owner.

Curtis Herring was the first owner to live on and build on the land. In 1858 he and Hollowell 01d, his brother-in-law, both of Live Oak County, purchased 200 acres of the Ryan grant. 2 Herring subsequently built a house there and raised a large family. 3 old and Herring were primarily stockraisers. 4 The two owned large herds, which would seem to indicate that he leased land adjacent to his 200 acres. Herring's brother Calvin lived in an adjacent dwelling, perhaps on the same property. 5

In 1893 the 200 acres and the improvements were sold to Willis Hunter, who moved from Jackson County to Live Oak County. 6 Hunter and his family resided on the property until 1899, when J.W. Nichols, of Live Oak Gounty, purchased the land and moved his family into the dwelling. Nichols gradually acquired extensive holdings north of the Tilden-Oakville Road in Live Oak County. When he died in 1954, his daughter, Marguerite Nichols Roper, inherited the property upon which LK66 is located. 8 The house has remained vacant since the death of J. W. Nichols. 9

\section{Sites 41LK197, 199}

Located on the H. N. Schwartz Ranch, 4lLK197 is situated 1600' south of the Frio River, 4300' north of State Highway 72 ; 4 ILK199 is situated 4500' south of the Frio River, 1800' north of State Highway 72.

* Sites having identical ownership histories are considered together. 
LK197 is composed of the remains of ranch/farm buildings and corrals; LK199 is composed of the foundation of a frame structure.

The "Schwartz Ranch" has traditionally been known as the "Mark Mahoney Ranch." The ranch included a major portion of 2479 acres granted in 1835 to Mark Killeley, a McMullen and McGloin colonist, by the Republic of Mexico. Upon Killeley's death in 1841 the grant passed to his daughters, Mary Heley and Rose Mahoney, both of the town of San Patricio. The sisters divided the property. Mrs. Mahoney retained the eastern half, and Mrs. Heley retained the western half. 10 Rose Mahoney kept her half of the grant, but in 1858 Mary Heley sold her 1374 acres to Thomas D. King, of San Patricio. King gave the title to the land to his son, John G. King, in 1859.11 Sites 197 and 199 both lie in the northern portion of King's 1374 acre tract.

In 1860 John King resided on the property with his family. He was engaged in farming and ranching and claimed to own a thousand head of stock. He was still living on the property in the $1880 \mathrm{~s}$ and $1890 \mathrm{~s}, 12$ although the Mahoneys had apparently purchased the land from him before 1887. It may be that the Mahoney and King families were related.

Mark K. Mahoney managed the ranch for his parents, Rose and Peter Mahoney, who remained in San Patricio. Mark and his brother Michael lived on the ranch from at least as early as 1884 until well into the twentieth century. 13 In 1887, upon the death of their mother, the brothers inherited portions of the Killeley grant. Of the six heirs of Rose Mahoney, only Mark and Michael resided in Live Oak County.14

Gradually, Mark Mahoney acquired possession of most of the estate from his brothers and sisters. Michael Mahoney sold his share to his brother in the early 1890s.15 Although the ranch appeared to be a wellmanaged business, the brothers borrowed.heavily from bankers in Fayette County. After the death of Mark Mahoney in 1897, his heirs, including his brother Michael, tried to maintain the enterprise. During the early twentieth century the ranch became the focus of cattle roundups. Once a year local cattlemen drove their herds to the Mahoney Ranch and sold them to cattle buyers from San Antonio. 16 Nevertheless, the Mahoney heirs could not meet their debts, and soon they began to lose portions of the ranch to their banker, Julius Schwartz. Between 1919 and 1941 the Schwartz family acquired the entire ranch. 17 None of the Schwartzes ever resided on the property. 18

Sites 4ILK73, 53 (Prehistoric)

Located on the Johnston Ranch, LK73 is situated $100^{\prime}$ east of the Live Oak-McMullen County line, 50' south of the Frio River; the historic component of LK53 is situated on Oppossum Hollow, 1.5 miles north of LK73. LK73 consists of the remains of a ranch/farm residence, with associated cemetery and refuse accumulation. The historic component of LK53 is the remains of a ranch/farm residence. 
Sites LK73 and the historic component of LK53 stand on 4605 acres originally granted by the Republic of Mexico to John Turner in 1835. Turner, a McMullen and McGloin colonist, resided in San Patricio and Harris Counties from the time of his emigration into Texas until the time of his death ${ }_{\text {ig }}$ In 1844 Turner sold his grant to Eli Williams, of Harris County. 19 Williams' son, Wesley, who lived in California, inherited the western half of the grant in 1852. In 1857 Wesley Williams sold the property to John Hodges, also a California resident. 20 Hodges, who moved from California to Goliad County, sold the property to George West, of Lavaca County, in 1882. The 2307 acre tract became part of George West's original ranch. ${ }^{21}$ In 1889 West sold the land to his business manager, Dillard R. Fant, of Live Oak County. Fant immediately sold the tract to James $M$. and John $T$. Brown, who moved from Goliad County to Live Oak County. 22 Later, the Browns acquired the eastern half of the Turner grant. In December of 1920 John T. Brown decided to homestead his portion of the Turner grant. His brother James had died in 1903, and John had received title to 3045 acres.

According to John Brown's homestead affidavit, the Turner grant was known in 1890 as the "Cavitt Ranch."23 William Cavitt, a rancher, resided in the vicinity during the mid-nineteenth century. In 1870 Cavitt owned a large herd of cattle. 24 Perhaps he grazed them on or near the Turner grant. Brown also noted that an old burned-out house was discovered on the property at the time he and his brother purchased the ranch. This might have been Cavitt's house. Brown further stated that he and his brother had built a house on the property and had made their home in this house from 1890 until after James Brown's death. John Brown vacated the house in 1910. Between 19185 and 1920 Brown leased the ranch to B. F. McCowan, of George West. ${ }^{25}$

Because access to the property has been denied by the present owner, the names of those interred in the cemetery at $L K 73$ are unknown. $\mathrm{J} . \mathrm{M}$. Brown and his wife are buried at Oakville. J. T. Brown is also buried at Oakville. The place of interment of J. T. Brown's wife might possibly be in the cemetery at LK73, and members of the Cavitt family may rest there also.

The "Cavitt Ranch" remained the property of the Brown family until 1936, when J. T. Brown failed to meet his mortgage payments. The trustee, the San Antonio Joint Stock Land Bank, sold the land in 1941. In 1963 the present owner, N. R. Johnston, acquired the tract. 26

Site $4 \operatorname{LLK} 15$

Located on the Davidson Ranch, this site is $50^{\prime}$ east of the Frio River, . 75 miles north of State Highway 72 . It consists of a refuse accumulation, with a possible associated historic structure. 
The source of LK15 may have been a related occupation site dating between 1900 and 1930, according to the surface collection of artifacts. It may have been the location in which the occupants of site LK73 deposited their trash. Both sites are located on portions of the John Turner grant, LK73 on the western half and LKI5 on the eastern.

Between 1835 and 1856 John Turner, Eli Williams and Wesley Williams owned the tract. 27 In 1856 Wesley Williams sold the 2307 acre eastern half to Charles Ellis, of California. In 1860 Ellis sold the property to B. F. Anthony, of Massachusetts. 28 In 1882 George West, of Lavaca County, purchased it, selling one-half in 1886 to Robert C. Barton, of Missouri, and selling the other half to James Mahoney, of Live Oak County. Mahoney and Barton exchanged property. At this point, in 1886, D. R. Fant owned the western half of the Turner grant; R. C. Barton owned the western half of the eastern half, and James Mahoney owned the eastern half of the eastern half. 29 In 1890 Barton and Fant sold their portions to J. M. and J. T. Brown, giving the Browns three-fourths of the Turner grant. ${ }^{30}$ LK15 is located on the western half of the eastern half of the grant. None of the owners resided on this portion of the grant.

After the death of J. M. Brown in 1903, J. T. Brown inherited the land upon which LK15 stood. In 1910 Brown gave the property to J. M. Brown's daughters, Susie Brown Reagan, wife of C. H. Reagan, and Mary Brown Reagan, wife of L. A. Reagan. ${ }^{1}$ The two couples mortgaged the land repeatedly during the 1920s, finally losing it in 1922. Subsequent owners were T. A. Vernor, of San Patricio County (1922-1945), D. D. Baucom (1945-1959), and Jack Davidson (1959-1976). Of all of the owners, only Baucom resided on the property. 32

Sites $41 \operatorname{LK} 159,168$

Located on the Schwartz Ranch, I mile south of State Highway 72 , 1.5 miles southeast of LK15, LK159 is composed of the remains of a stone ranch/farm residence; LK168 is a standing frame structure.

Sites LK159 and 168 are situated in what is known locally as the "Jarnes Mahoney Upper Pasture." The pasture is a portion of a 4605 acre tract awarded to John Turner, a McMullen and McGloin colonist, in 1835 by the Republic of Mexico. The history of the tract is identical to that of site LK15 through 1886, when James Mahoney acquired title to the 1100 acres upon which the dwellings are situated. The property remained in the possession of the Mahoney family until 1919.33

During the early twentieth century this portion of the Turner grant was used by the Mahoneys as a pasture. James Mahoney's son Darius, who was the only one of Mahoney's children residing in Live Oak County, apparently lived on the land from approximately 1904 until approximately 1910.34 James Mahoney resided in San Patricio County during the last three decades of the nineteenth century and during the first decade of the twentieth century. He died in 1914, and his property was partitioned among his children and his wife. 35 The sites 
are situated within the bounds of the portion awarded to Mahoney's wife Margaret. In 1919 she sold the property to a local resident, Kenneth Wimer, in order to raise enough money to pay her late husband's debts. 36

During 1919, title to this portion of the pasture was transferred numerous times. None of the owners resided in the county. The tract finally came into the possession of $\mathrm{H}$. N. Schwartz, a banker in Halletsville. 37 Considering the intricate manipulations surrounding the transference of title, it is extremely difficult to determine who may have lived on the property in this century. It is certain that of all of the owners, only Darius Mahoney lived in the area, perhaps in the frame structure. It is more likely that ranch foremen or ranch hands resided in the structure while working for the Schwartz family. 
Notes

1. Live Oak County, Texas, Deed Records [Vol. 1] "San Patricio Transcribed," PP. 153-158.

2. Ibid., Vol. A, pp. 258-259.

3. Live Oak County, Texas, Commissioner's Court Road Minutes, Vo1. 1, pp. 1, 6, 26, 31; Bill Bain to Dianna Everett, interview, August 5, 1977, George West, Texas.

4. United States Eighth Census, 1360 (Mf., Returns of Schedule One, Population, for Live Oak County, Texas, Southwest Collection, Lubbock, Texas); United States Ninth Census, 1870 (Returns of Schedule One, Population, for Live Oak County, Texas, Southwest Collection, Lubbock, Texas).

5. Live Oak County, Texas, Deed Records, Vol. C, p. 256.

6. Ibid., Vol. 1, p. 18

7. Ibid.; Commissioner's Court Road Minutes, Vol. 1, pp. 66, 88 .

8. Live Oak County, Texas Deed Records, Vol. 159, p. 235.

9. Bill Bain to Dianna Everett, interview, August 5, 1977, George West, Texas.

10. Live Oak County, Texas, Deed Records, Vol. A, p. 153.

11. Ibid., Vo1. 1-A, p. 301; Live Oak County, Texas, Transcribed Surveys, p. 291 .

12. United States Eighth Census, 1860 (Mf., Returns of Schedule One, Population, for Live Oak County Texas, Southwest Collection, Lubbock, Texas; Returns of Schedule Two, Agriculture, for Live Oak County, Texas, Southwest Collection, Lubbock, Texas); Live Oak County, Texas, Commissioner's Court Road Minutes, Vol. 1, pp. 6, 16, 21, 31, 51.

13. Live Oak County, Texas, Deed Records, Vol. L, pp. 323-336.

14. Live Oak County, Texas, Commissioner's Court Road Minutes, Vol. I, pp. $26,31,51,56,62,66, \overline{71,76 .}$

15. Live Oak County, Texas, Deed Records, Vo1. L, pp. 323-336, 573.

16. Buford Dugger to Alston Thoms, interview, August 31, 1977, Three Rivers, Texas. 
17. Live Oak County, Texas, Deed Records, Vo1. 56, PP. 509-510;

Vo1. 58, p. 305; Vol. 59, pp. 95, 436; Vol. 87, pp. 83-84.

18. Ott Reagan to Stephen Head, interview, August 9, 1977, Calliham, Texas.

19. Live Oak County, Texas, Deed Records [Vol. 1] "San Patricio Transcribed," p. 432.

20. Ibid., Vol. A, p. 113 .

21. Ibid., Vol. G, p. 279 .

22. Ibid., Vol. J, p. 123.

23. Ibid., Vol. 8, pp. 489-499.

24. Ibid., Index to Deed Records, Vol. 1, p. 4; United States Seventh

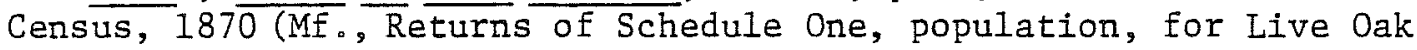

County, Texas; Returns of Schedule Two, Agriculture, for Live Oak County, Texas, Southwest Collection, Lubbock, Texas).

25. Live Oak County, Texas, Deed Records, Vol. 8, pp. 498-499.

26. Ibid., Vol. 86, p. 492.

27. Live Oak County, Texas, Deed Records [Vo1. 1] "San Patricio Transcribed," p. 432 .

28. Ibid., Vol. A, pp. 157-159.

29. Ibid., Vol. H, pp. 612-623.

30. Ibid., Vol. J, p. 13 .

31. Ibid., Vol. Q, pp. 50-53.

32. Ibid., Vol. 107, pp. 569-570.

33. Mrs. Frank DeGarmo, Pathfinders of Texas, 1836-1846 (Austin: Von Boeckmann-Jones, 1951), pp. 1-10.

34. Live Oak County, Texas, Commissioner's Road Minutes, Vol. 1, Pp. 88, $96,118,126,140$.

35. Live Oak County, Texas, Deed Records, Vo1. Y, pp. 260-261.

36. Ibid., Vol. 2, pp. 328-329.

37. Ibid., pp. 205-208, 399-401; Ott Reagan to Stephen Head, interview August 9, 1977, Calliham, Texas. 
Sites 41MC192 (Dusek), 193 (Bracken), 194 (Horton)

Located approximately 50' south of the Frio River on the BrackenHorton fence line, the three sites comprise the remains of three ranch/farm residences and outbuildings. Bracken $\# 2$, the easternmost, was a substantial home.

These sites lie on a 4605 acre tract originally granted to James M. Jean by the State of Texas in the 184ns. A. P. Noland, of Fort Bend County, patented the land in 1849.1 In 1853 Noland's heirs sold the property to Randall Jones, of Fort Bend County. ${ }^{2}$. Jones held the land for ten years. In 1853 he sold 1000 acres on the east side and 640 on the west side, leaving 2962 acres in the center. The sites are located on the center tract. ${ }^{3}$ None of these owners resided in the county. In 1863 Jones sold the center tract to Noah M. Badgett, of Pulaski, Arkansas. Badgett moved to Texas and settled in Crawford County. 4 In 1880 his heirs sold the property to Leonidas Wheeler, of McMullen County. A year later Wheeler sold the land to R. L. O'Neil, Daniel Yeamans, and H. M. Yeamans, all of Mclfullen County. ${ }^{5} 0$ 'Neil bought the others out, but in 1895 he lost the land to his bankers. In 1913 members of the Horton family bought the property. They retained it until 1958, when J. A. Bracken bought a 534 acre tract along the eastern edge. 6

As far as can be determined, no owner of the property ever resided on it. Until 1881 none lived in McMullen County. Nevertheless, squatters apparently did live on the property. In 1860 the family of John Doak moved from Atascosa County to McMullen County and built a home on the Frio three miles below Tilden. This corresponds with the location of the three sites. In 1862 the Doaks returned to Pleasanton, but Doak left his livestock on the Frio. Between 1862 and 1872 he frequently returned to the river to check his herd and to round up mustangs and wild cattle. 7

According to the 1870 census, the family of James R. O'Neil lived somewhere in the vicinity of the sites. 8 Perhaps this 0 'Neil was related to the $0^{\prime}$ Neil who purchased the property in 1881. According to the 1880 census, James $0^{\prime} \mathrm{Ne} i l$ had, by 1880 , moved to a ranch north of Tilden. Yet he could have resided in one of the three sites during the $1860 \mathrm{~s}$ and 1870s. In 1880 a prosperous sheep rancher, J. A. McQueen, was living in the vicinity of the sites. ${ }^{9}$ His ranching operation was substantial.10 He owned several hundred head of stock, employed four 
shepherds, a blacksmith, and two stonemasons. ${ }^{11}$ Once again, the exact location of the ranches is difficult to place precisely, although their descriptions fit the descriptions of the sites. It is entirely possible that since McQueen did not own the property, he may have leased it from $O^{\prime} \mathrm{Neil}$ and Yeamans.

\section{Site 41MC195 (Teal House)}

The original Teal ranch house is located on the C. T. Teal Ranch, $50^{\prime}$ south of Frio River, 2.5 miles downstream from Tilden. The site is composed of the remains of two ranch/Earm residences, one constructed of sandstone, one frame structure (burned).

In 1878 John and Amelia Barlow Teal, residents of Refugio County, bought 1500 acres in McMullen County and moved westward.12 During their first year of residence the Teals built a house close to the Frio River. In the same year a flood washed the home away. They subsequently built another house farther from the river. 13 In this home the Teals resided. Their son J. Albert and his wife, Mary Kuykendall Teal, lived with them. Late in 1878 John Teal deeded 200 acres, the site of the new house, to Mary K. Teal.14 Then in $1887 \mathrm{~J}$. Albert Teal designated the tract as his homestead. ${ }^{15}$ At some time between 1880 and 1887 John Teal moved farther down the Frio and built a home near the western edge of the Yarbrough Bend community. ${ }^{16}$ The original Teal homes have remained in the family since 1878 .

John and J. Albert Teal's ranching operation encompassed over 8000 acres. In 1880 John Teal owned 200 head of cattle. Both Teals also raised hogs, turkeys, and milk cows.17 Their descendants are also ranchers. Albert Teal and his family remained on the original. Teal Ranch. In 1935 Mary Teal gave her 200 acres to her son, Clarénce 'T. Teal, whose son now owns the property. 19

Sites 41MC15, 17, 71, 72 ("New"), 193, 74. (Cemetery)

Located on the J. A. Bracken Ranch, $50^{\prime}$ west of the Frio River, the sites are distributed over a distance of 1.5 miles along the river. The sites consist of the remains of the five ranch/farm residences; the cemetery contains two unmarked cairns.

These sites are located on a 640 acre tract originally granted in the late $1830 \mathrm{~s}$ to James Newcomb. In 1860 Newcomb's heirs sold the property to $W$. G. Thomas, a resident of Travis County. Thomas held the land until 1878, when he sold it to Leonidas Wheeler, of McMullen County. 20

Leonidas Wheeler had brought his family to McMullen County in 1869. The Wheelers lived on the Newcomb grant from 1869 to 1872 , although they did not own the property. They built a home on the land. The 
house was still standing in the early 1900s. It was located one-half mile west of the Bracken sites. 21 Wheeler was a stockraiser.22. In the mid-1870s he moved into Tilden and opened a store. With his profits he purchased large tracts of land. The first of these was the Newcomb grant, his old home. By 1880 wheeler had purchased over 16,000 acres of land and had begun to raise large herds of sheep. He hired managers to handle his herds and also employed his sons Monroe and William as herdsmen. 23

Several families lived and worked on the Wheeler Ranch during the late 1870s and early 1880s. In 1880 the census enumerator located them. Judging from his notes, the Bracken sites were probably occupied by a large family. The head of the family was George White, probably Wheeler's foreman. Residing in George White's household were: Peter and Amanda Harrison, White's parents-in-law; Ely and Winton Harrison, sons of the former couple; Bill T. Winters, son of an early settler of Yarbrough Bend; C. C. Davis, a laborer; Monroe Wheeler, son of the landowner; and two Mexican shepherds. According to the agricultural census of 1880 , White was renting 15,000 acres in return for which he gave the owner a share of the wool which he sheared. He had paid $\$ 400$ in wages in 1879, and he valued his land, fences, and buildings at $\$ 15,000.24$

From these records it may be deduced that Wheeler employed White as his manager, paying him a share of the profits made in the sale of the wool. The nature of the ranching operation necessitated the employment of numerous stockhands and laborers, for whom quarters must have been provided. The most logical explanation for the complex of sites on the Bracken Ranch is that the buildings housed White and Wheeler's other employees.

In 1883 Wheeler sold his ranch, including the Newcomb grant, to Thomas 0 'Connor, of Victoria County. 25 The Wheeler Ranch remained part of the O'Connor estate until 1902, when O'Connor sold it to the Two Rivers Ranch Company. The company was owned by A. B., James, and Joseph Kerr, all of San Antonio. 26 In 1936, the Kerrs sold 16,000 acres to J.A. Bracken. 27

Yarbrough Bend Cemetery (no number assigned)

Located on the J. F. Henry Ranch, 400' south of the Frio River, two miles downstream from the Bracken sites, the site consists of identifiable and unidentifiable cainns and markers, very disturbed by bulldozers and chaining equipment.

The Yarbrough Bend Cemetery lies within a 320 acre tract patented to Henry S. Foote, of Mississippi, in 1861.28 Foote's son inherited the land and then sold it to Leonidas Wheeler in 1879.29 Until 1893 the tract was part of the large wheeler Ranch. 
The cemetery was discovered in the mid-1950s by Joseph Coughran, a resident of Tilden. He examined a few of the markers and remembered two names, those of John Swanson Yarbrough and Frances Yarbrough. 30 For over 20 years access to the property has been denied by the present owners. In 1964, however, a descendant of the Yarbroughs, Mrs. Gladys Ritter, of San Antonio, obtained permission to examine the markers. She recorded the following information contained on the stones:

$$
\begin{aligned}
& \text { a. "John Swanson Yarbrough Died October 21, } 1862 \\
& \text { Aged } 88 \text { Years" } \\
& \text { b. "Frances Yarbrough Died (month and day illegible) } \\
& \text { Aged } 55 \text { years" } \\
& \text { c. "Infant Daughter of Joseph Walker and Amanda Yarbrough" } \\
& \text { d. "Sorrow-Zevish Died July 2, 1874" }
\end{aligned}
$$

Eight additional graves were marked, but the inscriptions were illegible. Mrs. Ritter did attempt to obtain information from local residents in order to identify the remaining graves. She ascertained that the following persons were probably interred in the cemetery: Mr. and Mrs. William C. Walker; Frank Drake (brother of Mrs. Walker); an infant member of the Winters family; Amanda Harrison; and a member of the Williams family. 31

All of these families were resident in the county by at least 1870.32 The Yarbrough, Walker, Winters, and Harrison families were all related by marriage. 33 As the Yarbrough Bend community seems to have been in the nature of an extended family, the cemetery must have served as a family as well as a community burial ground.

\section{Site 41MC91}

Located on the Libersat Ranch, on San Miguel Creek, approximately 1.25 miles upstream from its confluence with the Frio River, the site consists of a frame structure, refuse accumulation, and remains of a sandstone structure.

This 738 acre tract was patented to Dewitt C. Lyons in 1838 by the Republic of Texas. 34 In 1878 Lyons, who lived in Karnes County, sold his property in McMullen County to R. S. Flourney, a banker from Jackson County. 35 Flourney sold it immediately to L. D. Young, a Baptist minister residing in Tilden. ${ }^{36}$ In 1882 Young sold the land to Leonidas Wheeler. 37 In the same year wheeler sold the land to W. N. Huff, John Teal's son-in-law. 38 Huff lived on the property for two years, selling it in 1884 to William A. Hill. Hill lived on the property until he lost it to a San Antonio bank in 1890.39 In 1891 the bank sold the 738 acres to J. Albert and W. Ed Teal, sons of John Teal. 40 
Both resided elsewhere. Upon Albert Teal's death, in 1941, the Lyons grant was partitioned among his heirs. ${ }^{1}$ The house and land went to Amelia Teal Walker. In 1972, Alice Walker Tausch inherited the property, which she sold to Murphy Libersat. 42

During the late 1860 s and 1870 s two brothers, James and Allen Franklin, ranched on San Miguel Creek in the vicinity of the site. Both had large families. Both were heavily involved in the cattle industry. Together their herds numbered well over 2000.43 They may have occupied the older portion of MC91.

During the 1880s two families resided in adjacent dwellings in the vicinity of the site. The first, or easternmost, dwelling was the home of a Mexican wagoner named Rocha Lesso. In the adjacent dwelling lived Allen Lowe, a black man and a farmer. The Lowe family was employed by ranchers in the area. 44

As the families who owned the property at this time never resided on it, the families described above may have occupied the older portion of the site. During the later years of the century, the Huffs and Hills may have occupied the frame structure. In following years, any one of John Teal's numerous progeny may have lived on the site. ${ }^{45}$

\section{Sites 41MC166, 168 (Prehistoric)}

Located on San Miguel Creek, eight miles upstream from its confluence with the Frio River, MC166 is a refuse accumulation; MC168 contains the remains of a ranch/farm residence.

The two sites lie within the bounds of an 1190 acre tract of land patented in 1875 to the heirs of Green Lee, who was a veteran of the Texas Revolution. 46 Lee's heirs sold the land to Charles Lyford, of McMullen County. 47 Lyford built a home on the property and lived there from 1882 to 1888.48 In 1888 he leased the tract to a Tilden resident. In 1889, Lyford sold the Lee grant to James A. Gillis, of San Antonio, who leased it to J. M. Martin. Martin, who resided in Tilden, grazed cattle on the ranch. ${ }^{49}$ In 1901 Gillis sold the land to the Teal family. Neither of the new owners lived on the property. 50

Two occupants of the house built by Lyford have been identified. In 1888, after Lyford moved, a black family named Garrett occupied the house. 51 As J. M. Martin was leasing the land, it seems plausible to suggest that the Garretts served as caretakers. The family moved at an unknown date and later, during the 1920s, an elderly man named John Kinnard lived alone on the property.52 Kinnard served as a caretaker for the Teals.

The Lee grant was purchased from the W. E. Teal estate by Guy Teal, his son, in 1938. Since 1962 James $W$. Teal has owned the property. 53. 
Sites 41MC66 (Byrne Ranch Cemetery), 55 (Prehistoric)

Both sites are located on the old Byrne Ranch; the cemetery is presently on the Doughty Ranch; the other site is on the Chandler Ranch. The cemetery is a cluster of at least eight graves, six marked and two unmarked. The historic building site comprises the remains of a sandstone structure and a refuse accumulation.

Gravesite MC66 is located west of the Frio River on property which was originally granted in 1835 by the Republic of Mexico to Matthew Byrne. 54 Byrne, who resided in New York, died in 1835 and left the land to his sisters, Mary Boyd and Catherine Willis, both of New York. The sisters sold the land to Leonidas Wheeler in 1878.55 Wheeler was the first local owner of the property. In 1887 wheeler sold the property to Charles Robertson Byrne, who was not related to Matthew Byrne. 56

During these years at least six local residents came to be buried in "Graveyard Hollow," now known as the Byrne Ranch Cemetery. Two unmarked cairns appear to be the oldest interments. In 1869 the first dated interment, that of three-year-old Jasper Harrison, occurred. Next, in 1887, was that of Mary Dilworth, wife of George Dilworth. Mr. Dilworth was interred there in 1894. The final burial came in 1911, when Byrne's sister Eliza died. 57

The Byrne family lived one-half mile south of the cemetery, in a house erected between 1882 and 1900.58 The Byrne house, which is still standing, was built on a 4605 acre tract purchased by Byrne from Leonidas Wheeler in 1882.59 This was the Byrne home from 1882 until at least 1918,60 when Charles Byrne died. Byrne left the house and several hundred acres to his son Walter. 61 The tract of land containing the cemetery became the property of Byrne's daughter, Ida Holland.62 It now belongs to Eric Doughty, of Calliham.

The stone structure at MC55 was situated one mile southeast of the Byrne house. 'It is conceivable that the occupants of this dweling were among those who were buried in the unmarked graves in the cemetery. After comparison of the dates of interment of the other graves with the census returns of 1870 it seems plausible that the family of Peter Harrison had lived in the vicinity during the late 1860s. Furthermore, the family of George Dilworth lived near the Harrison family. 63 Either of these may have occupied the stone structure.

In addition, in 1880 numerous squatters resided along the west bank of the river at various points between the mouth of San Miguel Creek, to the west of the cemetery, and the Grover Ranch, to the east of the cemetery. 6.4 In 1880 the Wheeler Ranch encompassed this property. Both Wheeler and Byrne allowed squatters to live on the ranch. 65 Three families of squatters, according to the 1880 census, lived in the area. The first was that of Charles Lampkin, a farmer. Lampkin's neighbor on the southeast was Charles Courtney, an Englishman and a farmer. 
Southeast of Courtney's farm was the house of Eusabio Gomez, a shepherd.66 Gomez may have been employed by wheeler or by D. C. Grover, both of whom were sheep raisers. Any of these families may have resided in the stone structure located on the Byrne Ranch. If so, then there are other structures yet to be discovered in the area.

\section{Site 41MC4 (Gravesite)}

Located on the Morgan Ranch, .25 miles north of State Highway 72 , .75 miles west of Calliham, the site is composed of a cluster of five unmarked interments enclosed by a substantial stone fence; remains of a stone structure have been discovered just north of the grave; a standing frame house and the remains of another frame structure lie east of the cemetery.

Local residents relate two stories to explain the presence of the graves. In one version, a family of squatters named Murphy lived in the area about 100 years ago. The parents and their three children mistakenly ate mistleberries and died. Unknown persons then buried the family. 67 A search of census records reveals the presence of no Murphys. No one named Murphy ever owned this property or any other in the neighborhood. However, because of the squatter population of the area during the nineteenth century, the story retains some plausibility. In another version, a group of people contracted diphtheria while traveling through the area. Those who died were supposedly buried there, near the road. 68 There is no documentary support for this story. However, the graves do lie very near the old Oakville-Tilden road. According to local tradition, people traveling westward to the. California gold field came through this part of McMullen County. 69

Finally, an inscription found above one of the graves does not aid in identifying the site. Etched on the interior face of the west wall are the dates "1921-1821" (sic). This is followed by the words "C. E. H. E. SAGE died 1921."70 Perhaps a family of squatters named Sage lived in the area, but they are not represented in the records. A more plausible explanation for the inscription is that it is graffiti, because the present owner of the land allows public camping in the vicinity of the site.

The property upon which site MC4 stands is the eastern haff of a 4605 acre grant given to a McMullen-McGloin colonist in 1835. In 1845 the heirs of James Garner sold the grant. 72 Between 1845 and 1877 the grant had no resident owner. In 1877 Dewitt C. Grover, of Bee County, purchased the land and moved to McMullen County. ${ }^{3}$ ' Grover lived on the property, and he also leased part of it to Amos C. Miles, a farmer. 74 According to the census of 1880 Miles lived in the area. 75 Two houses were constructed about 500 feet southeast of the gravesites. 76 The easternmost, or older house, still stood in 1915, but was demolished before 1935. The newer house was built before 1915 and is presently occupied by the owner of the land. 77 
According to the Census of 1880 three families of squatters lived on this side of the river near the gravesite. Their nearest neighbors were J. T. Calliham, a sheep rancher, on the east, and Charles R. Byrne, a cattleman, on the west. ${ }^{78}$ These families may have lived either on the Byrne Ranch or on the Grover Ranch. (For a description of these families, refer to the history of site MC66.)

In 1890 and 1891 D. C. Grover deeded this portion of his property to his son, John H. Grover. In 1891 John Grover was living on the property. ${ }^{79}$ In 1906 he sold the land to L. A. Reagan. Reagan sold it in 1912 to a San Antonio businessman. 80 In 1935 the property was sold to Thomas Morgan, the present owner. ${ }^{81}$ Perhaps the Grovers are buried in the cemetery, as they are not buried in the organized cemeteries in Tilden, Calliham or Oakville. 82

\section{Site 41MC6 (Gravesite)}

Located on the Snoga Ranch, .25 miles north of State Highway 72 , .25 miles west of Calliham, the site consists of two cairns, each marked with large headstones.

Gravesite MC6 comprises two cairns constructed in 1869 . The occupants of the graves, William B. Morris (1802-1869) and Martin Luther Taylor (1842-1869), were killed in 1869 as a result of the Taylor-Sutton feud then raging in south Texas.83 According to legend, the two men were engaged in operating a ranch in McMullen County somewhere along the Frio River. 84 In 1868 the two had moved from Dewitt County to McMullen County in order to escape the feud between Taylor's cousins and the family of William Sutton. 85 Taylor had recently married Morris' daughter, Sophronsa.

In November of 1869 a group of former Sutton employees came to Taylor's Ranch, took Taylor and Morris captive, and took them southward toward the Tilden-Oakville Road. Apparently, the captors intended to turn the two men over to the authorities, for reasons unknown... As they neared the road, the two captives attempted to escape, were killed, and were buried on the spot. 86

The story is substantially correct. The census of 1870 lists both wives, living together with no males in their household. 87 They lived on San Miguel Creek about five miles upstream from its confluence with the Frio River. 88 In addition, the graves of the men lie very close to the Oakville-Tilden Road.

Sites 41MC175, 46

The sites are located on the Lark Ranch; MC175 is situated 150' southeast of the Frio River on a small creek; MC46 is situated on Opossum Creek, approximately 4.5 miles northeast of MC175. MC175 is a standing frame structure; MC46 is the remains of a stone structure. 
Both sites are located on a grant given to Michael o'Boyle, an Irish colonist, by the Republic of Mexico. ${ }^{9}$ Until 1898 the property was held by absentee owners. In 1898 it was purchased by William Harman, of McMullen County. 90 He mortgaged the land and lost it to a bank, which sold it to Lewis W. Snowden, of Tilden, in 1897.91 Snowden's son's family lived in a house on the property during the first few years of the twentieth century. ${ }^{92}$ In 1903 Snowden sold the property to Otto Askey, of Gonzales County.93 Since 1905 every owner of the property has been absentee. Ranch foremen and workers have lived in the house. 94 The date of its construction is unknown. The present owners, Charles Lark and Mabel Gies, reside in New Jersey.

MC46 is located in the eastern portion of the grant, on Opossum Creek. Only three ranches are known to have been established on the Creek during the nineteenth century. In local tradition, I. A. Pierce owned a ranch in the area, but the records do not substantiate the tradition. 95 The Census of 1880 , however, listed two potential candidates: first, C. C. Brooks, a renter, and second, Captain J. M. Shelley and Joseph Dunn, Shelley's brother-in-law.96 Shelley built a large ranch and by the turn of the century was regularly shipping livestock to San Antonio. 97 He may have leased the property, but he never owned it. Either site may have been built by lessees or by squatters during the two extended periods of absentee ownership, 1835-1898 and 1905-1976.

\section{Site $41 M C 185$}

Located on the Morrill Ranch on Opossum Creek 4.5 miles north of State Highway 72 , the site consists of the remains of ranch/farm structures.

The griginal owner of this land was John Fadden, a McMullen-McGloin colonist. 98 Fadden always resided in San Patricio. When he died, in 1850, he left the property to his sister, Catherine Gaffney, of San Patricio. 99 Upon her death, in 1882, her heirs sold the property to Daniel Fox, of Refugio County. 100 Fox, who died in 1890 , left the property to his children, who sold it immediately to Leonard Jacob, a New York land speculator. Jacob died in 1908, and the land came into the possession of his sons. 101 In 1925, the sons formed the Leonard Jacob Corporation. The Jacobs used their McMullen County land as a sheep and cattle ranch, hiring foremen to oversee the operation.102 The Leonard Jacob Ranch encompassed more than 11,000 acres in McMullen and Live Oak Counties. 103 In 1941 the ranch was sold to a San Antonio resident, whose wife later sold it to George P. Morrill, a San Antonio attorney.104 The ranch has never had a resident owner.

However, the censuses of 1870 and 1880 indicate that squatters may have lived in the vicinity. 105 One, a Captain J. M. Shelley, was very prosperous. For a discussion of possible occupants of the site, refer to the site history of MC46. 


\section{Site $41 \mathrm{MC} 214$}

Located on the Morrill Ranch, on Opossum Creek, five miles upstream from its confluence with the Frio River, the site consists of remains of a substantial stone ranch/farm residence, fences, and outbuildings.

This site is located on a 640 acre tract of land purchased from the state in 1896 by Leonard Jacob, a New York land speculator. 106 Before 1896 the property was state land. The tract lies in the southernmost portion of the 11,000 acre Leonard Jacob Ranch.107 Jacob and his sons retained title to the land intil 1941, when they sold most of the ranch to Thaddeus J. Brownson, a San Antonio resident. In 1965 Brownson and his wife sold the ranch to George P. Morrill, a San Antonio attorney. 108 During the entire history of the ranch, no owner ever resided on or near the property. All of the owners employed resident foremen who may have lived at the site.

In addition numerous squatters resided in the vicinity during the 1870 s and 1880 s.109 For a discussion of possible occupants of the site, refer to the history of site MC46. 
Notes

1. McMullen County, Texas, Deed Records [Vol. 1] "San Patricio Transcribed," Pp. 193-196; Abstracts of All Original Texas Land Titles (Austin: General Land Office, $\overline{1942), \text { IV }}, \bar{p} .693$; Map of McMulien County (Austin: General Land Office, 1876).

2. McMullen County, Texas, Deed Records, Vol. B, p. 89.

3. Ibid., Vol. C, p. 329 .

4. Ibid., Vol. J, p. 208.

5. Ibid., Vol. P, pp. 451-452.

6. Ibid., Vol. 19, p. 101.

7. R. J. Lauderdale and J. M. Doak. Life on the Range and on the Trail (San Antonio: Naylor, 1936), pp. 1-1

8. United States Ninth Census, 1870 (Returns of Schedule One, Population, for McMullen County, Texas; Returns of Schedule Two, Agriculture, for McMullen County, Texas.)

9. Ibid.

10. McMullen County, Texas, Deed Records, Vo1. C, pp. 102, 335.

11. United States Tenth Census, 1880 (Returns of Schedule One, Population, for McMullen County, Texas; Returns of Schedule Two, Agriculture, for McMullen County, Texas.)

12. Mary Ruth Teal Franklin to Dianna Everett, interview, October 13, 1977, Tilden, Texas.

13. McMullen County, Texas, Deed Records, Vol. A, pp. 351-360; Abstracts of All Original Texas Land Titles (Austin: General Land Office, 1942), $\overline{I V}, \bar{p} . \overline{697}$; Map of McMulien County (Austin: General Land Office, 1876).

14. Mary Ruth Teal Franklin, October, 1977.

15. McMullen County, Texas, Deed Records, Vol. B., p. 105.

16. Ibid., Vol. G., p. 498.

17. United States Tenth Census, 1880 (Returns of Schedule One, Population, for McMullen County, Texas; Returns of Schedule Two, Agriculture, for McMullen County, Texas.) 
18. Mary Ruth Teal Franklin, October, 1977.

19. McMullen County, Texas, Deed Records, Vol. 17, pp. 2-3.

20. McMullen County, Texas, Deed Records, Vo1. A., p. 423; Abstracts of All Original Texas Land Titles (Austin: General Land Office, 1942); Map of McMullen County (Austin: General Land Office, 1876).

21. Clifton Wheeler to Dianna Everett, interview, October 14, 1977 , Tilden, Texas.

22. United States Ninth Census, 1870 (Returns of Schedule One, Population, for McMullen County, Texas.)

23. Clifton Wheeler, October, 1977.

24. United States Tenth Census, 1880 (Returns of Schedule One, Population, for McMullen County, Texas; Returns of Schedule Two, Agriculture, for McMullen County, Texas:)

25. McMullen County, Texas, Deed Records, Vol. H, pp. 563-575.

26. Ibid., Vol. K, pp. 568-580.

27. Ibid., Vo1. 18, p. 265.

28. McMullen County, Texas, Deed Records, Vol. A, pp. 50-55.

29. Ibid., Vol. D, p. 91.

30. Joseph Coughran to Dianna Everett, October 13, 1977, Tilden, Texas.

31. Gladys Ritter to Dianna Everett, August 10, 1977, Tilden, Texas.

32. Historical Marker Files, McMullen County (Mss., Texas State Historical Commission, Austin, Texas).

33. Gladys Ritter, August, 1977.

34. Abstracts of A11 Original Texas Land Titles (Austin: General Land Office, 1942), IV, p. 694; Map of McMullen County (Austin: General Land Office, 1876).

35. McMullen County, Texas, Deed Records, Vol. B, p. 3.

36. Ibid., Vol. D, p. 87.

37. Ibid., p. 92 .

38. Ibid., VoI. E., p. 500 . 
39. Ibid., p. 553.

40. McMullen County, Texas, Deed Records, Vol. H, pp. 435-437.

41. Ibid., Vol. 28, p. 605.

42. Ibid., Vol. 115, P. 4.

43. Lauderdale and Doak, pp. 1-11.

44. United States Ninth Census, 1870 (Returns of Schedule One, Population, for McMullen County, Texas; Returns of Schedule Two, Agriculture, for McMullen County, Texas.)

45. United States Tenth Census, 1880 (Returns of Schedule One, Population, for McMullen County, Texas; Returns of Schedule Two, Agriculture, for McMullen County, Texas.)

46. McMullen County, Texas, Deed Records, Vol. D., p. 436; Abstracts of Al1 Original Texas Land Titles (Austin: General Land Office, 1942), IV, p. 694 .

47. McMullen County, Texas Deed Records, Vol. D, p. 518.

48. Clifton Wheeler to Dianna Everett, interview, October 14, 1977 , Tilden, Texas.

49. Ibid.; McMullen County, Texas, Deed Records, Vol. J, p. 236.

50. McMullen County, Texas, Deed Records, Vol. K, p. 186.

51. Clifton Wheeler to Dianna Everett, interview, August 11, 1977 , Tilden, Texas.

52. Ibid.; Mary Ruth Teal Franklin to Dianna Everett, interview, October 13, 1977, Tilden, Texas:

53. McMullen County, Texas, Deed Records, Vol. 89, pp. 389-390.

54. Abstracts of All Original Texas Land Titles (Austin: General Land Office, 1942), IV, p. 688 .

55. McMullen County, Texas, Deed Records, Vol. B, P. 108.

56. Ibid., Vo1. E, p. 491.

57. List compiled from personal observation by the author at the Byrne cemetery, August 12, 1977.

58. Abstracts of All Original Texas Land Titles (Austin: General Land Office, 1942), IV, P. 688 . 
59. McMullen County, Texas, Deed Records, Vol. C, p. 500.

60. Charles R. Byrne, New Encyclopedia of Texas (Dallas: Texas Development Bureau, 1927); I, p. 505.

61. McMullen County, Texas, Deed Records, Vol. 40, p. 266.

62. Ibid., Vo1. 104, p. 291.

63. United States Ninth Census, 1870 (Returns of Schedule One, Population, for McMullen County, Texas.)

64. United States Tenth Census, 1880 (Returns of Schedule One, Population, for McMullen County, Texas.)

65. Clifton Wheeler, 1977; Pleasanton Express, October 26, 1966.

66. United States Tenth Census, 1880 (Returns of Schedule One, Population, for McMullen County, Texas.)

67. Ott Reagan to Stephen Head, interview, August 9, 1977, Calliham, Texas.

68. Thomas Morgan to Dianna Everett, interview, August 10, 1977, Ca1liham, Texas.

69. Live Oak County Centennial, 1856-1956 (George West, Texas: Press of the George West Enterprise, 1956), n.p.

70. Personal observation by the author, August 10, 1977.

71. Abstracts of Al1 Original Texas Land Titles (Austin: General Land Office, 1942), IV, p. 688 .

72. McMullen County, Texas, Deed Records, Vol. 1-A, p. 63.

73. Ibid., Vo1. A, pp. 99-100.

74. "McMullen County Centennial Essays," (Mss. McMullen County Museum Association, Tilden, Texas).

75. United States Tenth Census, 1880 (Returns of Schedule One, Population, for McMullen County, Texas.)

76. Thomas Morgan, August, 1977.

77. McMullen County, Texas, Book of Plat Records, p. 4.

78. United States Tenth Census, 1880 (Returns of Schedule One, Population, for McMullen County, Texas.) 
79. McMullen County, Texas, Deed Records, Vol. I, p. 98.

80. Ibid., Vol. 16, p. 331 .

81. Ibid., Vol. 0, pp. 307, 489.

82. Personal observation by the author, August 11, 1977.

83. Personal observation by the author, August 10, 1977; Charles Walker to Dianna Everett, interview, August 10, 1977. Walker's grandfather married Taylor's widow.

84. Walker, October, 1977.

85. Jack H. Day, The Taylor-Sutton Feud (Austin: Murray and Son, 1937), pp. 5-10.

86. Ibid.

87. United States Ninth Census, 1870 (Returns of Schedule One, Population).

88. United States Tenth Census, 1880 (Returns of Schedule One, Population).

89. Abstracts of All Original Texas Land Titles (Austin: General Land Office, 1942), IV, p. 688; McMullen County, Texas Deed Records, Vol. F, pp. 30-31.

90. McMullen County, Texas, Deed Records, Vol. G, pp. 632-633.

91. Ibid., Vol. J, pp. 474-476.

92. Gladys Snowden Wheeler to Dianna Everett, interview, August 15, 1977, Tilden, Texas.

93. McMullen County, Texas, Deed Records, Vo1. K, pp. 500-501.

94. Gladys Wheeler, August, 1977.

95. Joseph Pate Smyer, A History of McMullen County (unpublished Master's thesis, University of Texas, 1952), P. 85 .

96. United States Tenth Census, 1880 (Returns of Schedule One, Population, for McMullen County, Texas.)

97. Clifton Wheeler to Dianna Everett, interview, October 14, 1977 , Tilden, Texas.

98. Abstracts of All Original Titles to Texas Lands (Austin: General Land Office, $1 \overline{942), ~ I V, ~ P . ~} 688$.

99. McMullen County, Texas, Deed Records, Vol. F, p. 182. 
100. Ibid., Vol. 4, p. 308.

101. Ibid.

102. Gladys Wheeler, October, 1977.

103. McMullen County, Texas, Deed Records, Vo1. 30, p. 322.

104. Ibid., Vol. 93, p. 541.

105. United States Ninth Census, 1870 (Returns of Schedule One, Population); United States Tenth Census, 1880 (Returns of Schedule One, Population).

106. Abstracts of All Original Titles to Texas Lands (Austin: General Land Office, 1942), IV, p. 702 .

107. Map of McMullen County (Austin: General Land Office, 1876, 1976).

108. McMullen County, Texas, Deed Records, Vol. 93, p. 541.

109. United States Ninth Census, 1870 (Returns of Schedule One, Population; Returns of Schedule Two, Agriculture); United States Tenth Census, 1880 (Returns of Schedule One, Population; Returns of Schedule Two, Agriculture). 
REFERENCES CITED

Abs.tracts of All Original Texas Land Titles

1942 General Land Office, Austin.

Atascosa County Centennial Association

1970 Program and History of Atascosa County, 1856-1956. Centennial Association.

Bender, A. S.

1933 Opening Routes Across West Texas, 1848-1850. Southwestern Historical Quarterly, 37:130-131.

Bonnell, G. W.

1840 Topographical Description of Texas, to which is Added an Account of the Indian Tribes. Clark, Wing, and Company, Austin.

Byrne, J.

1950 A Short History of the Byrne Family. Privately printed. Carroll, H. B.

1943 Texas County Histories: A Bibliography. Texas State Historical Society, Austin.

Castañeda, C. E.

1936-1958 Our Catholic Heritage in Texas, 1519-1936. Edited by

Paul J. Foik. 7 vols. Von Boeckmann-Jones, Austin.

Connor, S. V.

1971 Texas: A History. Thomas Y. Crowell Company, New York. $\operatorname{Cox}, \mathrm{J}$.

1894 Historical and Biographical Record of the Cattle Industry and the Cattlemen of Texas. 2 vols. Woodward and Tiernan Co., St. Louis.

Dale, E. E.

1930 The Range Cattle Industry. University of Oklahoma Press, Norman. 
Davis, E. A., editor

1927 The New Encyclopedia of Texas. Texas Development Bureau, Dallas.

Day, J. H.

1937 Taylor-Sutton Feud. Murray and Son, San Antonio.

Degarmo, Mrs. F.

1951 Pathfinders of Texas, 1836-1846. Von Boeckmann-Jones, Austin.

Dixon, S. H. and L. W. Kemp

1932 The Heroes of San Jacinto. Anson Jones Press, Houston.

Dobie, J. F.

1929 A vaquero of the Brush Country. Southwest Press, Dallas.

Gamme11, H. P. N.

1898 The Laws of Texas, 1822-1897. 10 vols. Gammell Book Co., Austin.

Hardy, D. H., editor

1907 A Twentieth Century History of Southwest Texas. 2 vols. Lewis Publishing Co., New York.

Henderson, M. V.

Minor Empressario Grants. Southwestern Historical quarterly, 31:295-324; 32:1-28.

Hendricks, S. B.

The Somerville Expedition to the Rio Grande, 1824. Southwestern Historical Quarterly, 23:112-140.

Hollon, E. and R. L. Butler, editors

1956 William Bollaert's Texas. University of Oklahoma Press, Norman.

Hunter, J. M.

1963 The Trail Drivers of Texas. 2 vols. Argosy-Antiquarian Ltd., New York. 
Jenkins, J. H., editor

1965 Cracker Barrel Chronicles: A Bibliography of Texas Town and County Histories. Pemberton Press, Austin.

Johnson, F. W.

1914 A History of Texas and Texans. Edited by E. C. Barker and E. W. Winkler. American Historical Society, Chicago.

Kocher, A. E.

1912 Reconnaissance Soil Survey of Southwest Texas. Government Printing office, Washington.

Lauderdale, R. J. and J. M. Doak

1936 Life on the Range and on the Trail. Nay1or Co., San Antonio.

Lehmann, V. W.

1969 Forgotten Legions: Sheep in the Rio Grande Plain of Texas. Texas Western Press, EI Paso.

Lindholm, T.

1950 History of Oakville. Unpublished Masters thesis.

Texas A \& I University.

Live Oak County Centennial, 1856-1956

1956 The Press of the George West Enterprise, George West, Texas.

Live Oak County, Texas

1850-1913 Commissioners Court Minutes.

1835-1972 Deed Records.

1835-1880 Transcribed Surveys.

Lynn, W. M., D. E. Fox and N. O'Malley

1977 Cultural Resource Survey of Choke Canyon Reservoir, Live Oak and McMullen Counties, Texas. Texas Historical Commission, Office of the State Archeologist, Archeological Survey Report 20. 
McMullen County Museum Association

ms. McMullen County Centennial Essays. Manuscript on file at McMullen County Museum, Tilden, Texas.

McMullen County, Texas

1900-1930 Book of Plat Records.

1900-1977 Combined Birth and Death Register.

1877-1900 Commissioners Court Minutes.

1835-1977 Deed Records.

Map of Live Oak County

1959 General Land Office, Austin.

Map of Momuleen County

1876, 1959, 1976 General Land Office, Austin.

Martin, M. F.

1976 Zachariah Martin, 1790-1873. Privately printed.

May, M. K. and F. W. Zavisch

ms. Yarbrough Bend. Texas Historical Commission, Austin.

Mayer-Oakes, W. J.

1977. Proposal for Cultural Resources Investigation, Archeological and Historical, Phase I, Nueces River Project, Texas, in response to Bureau of Reclamation RFP 50-V0897. Cultural Resources Institute, Texas Tech University, Lubbock.

Nance, J. M.

1964 Attack and Counterattack: The Texas-Mexican Frontier, 1842. University of Texas Press, Austin.

Oberste, W. H.

1953 Texas Irish Empresarios and Their Colonies. Von Boeckmann-Jones, Austin.

Pleasanton Express

1966 October 26, 1966. 
Ray, W. S.

1949 Austin Colony Pioneers. Privately printed, Austin.

Rock, J. L. and W. I. Smith

1878 Southern and Western Guide for 1878. A. H. Granger, St. Louis.

Secretary of State Papers

Papers Relating to Colonization in the State of Coahuila and Texas, 1826-1835. Texas State Library, Austin.

Skaggs, J。

1973 The Cattle Trailing Industry: Between Supply and Demand, 1868-1890. The University Press of Kansas, Lawrence, Kansas.

Smyer, J. P.

1952 A History of McMullen County. Unpublished Masters thesis. University of Texas, Austin.

Sowe11, A. J.

1900 Early Settlers and Indian Fighters of Southwest Texas.

B. C. Jones and Co., Printers, Austin.

State of Texas, Department of Agriculture

1910 Yearbook. Von Boeckmann-Jones, Austin.

State of Texas, General Land Office, Archives Division

Original Titles to Lands Granted in McMullen and McGloin's Colony. Spanish Archive, Vols. LIX-LX, Austin.

Record of Translations of Empresario Contracts. Ms. volume, Spanish Archive, Austin.

State of Texas, Department of Agriculture, Insurance, and Statistics

1882 Resources, Soil, and Climate of Texas. A. H. Belo and Co., Galveston.

1889 First Annual Report of the Agricultural Bureau, 1887-1888. State Printing office, Austin.

1890 Second Annual Report of the Agricultural Bureau, 1888-1889. State Printing Office, Austin. 
1893 Fifth Annual Report of the Agricultural Bureau, 1891-189?. Jones and Co., Austin.

1894 Sixth Annual Report of the Agricultural Bureau. Jones and Co., Austin.

1897 Ninth Annual Report of the Agricultural Bureau. Jones and Co., Austin.

1904 Agricultural and Statistical Report, 1904. Von BoeckmannJones, Austin.

1905 Agricultural and Statistical Report, 1905. State Printing Co., Austin.

Thonhoff, R. H.

1971 San Antonio Stage Lines, 1847-1881. Texas Western Press, E1 Paso.

United States Department of Agriculture

1941 Aerial Reconnaissance Photographs, Soil Conservation Service. United States Department of the Interior, Office of the Census

1860 The Eighth Census, 1860. Returns of Schedule One, Population. Manuscript on microfilm, Southwest Collection, Texas Tech University, Lubbock.

1870 The Ninth Census, 1870. Returns of Schedule One, Population. Manuscript on microfilm, Southwest Collection, Texas Tech University, Lubbock.

1870 The Ninth Census, 1870. Returns of Schedule Two, Agriculture. Manuscript on microfilm, Southwest Collection, Texas Tech University, Lubbock.

1872 Compendium of the Ninth Census, 1870. Government Printing Office, Washington.

1880 The Tenth Census, 1880. Returns of Schedule One, Population. Manuscript on microfilm, Southwest Collection, Texas Tech University, Lubbock.

1880 The Tenth Census, 1880. Returns of Schedule Two, Agriculture. Manuscript on microfilm, Southwest Collection, Texas Tech University, Lubbock.

1883 Compendium of the Tenth Census, 1880. Government Printing office, Washington. 
Utley, R. M.

1967 Frontiersmen in Blue: The U.S. Army and the Indian, 1848-1865. Macmillan, New York.

Warner, C. A.

1939 Texas Oil and Gas Since 1543. Gulf Publishing Co., Houston.

Webb, W. P.

1931 The Great Plains. Ginn and Co., Boston.

Wentworth, E. N.

1948 America's Sheep Trails. Iowa State College Press, Ames, Iowa. 


\section{INTERVIEWS}

Bain, Bill. George West, Texas, August, 1977.

Chandler, W. P. Calliham, Texas, August, 1977.

Coughran, Joe. Tilden, Texas, October, 1977.

Dugger, Buford. Three Rivers, Texas, August, 1977.

Franklin, J. F. Tilden, Texas, October, 1977.

Franklin, Mary Ruth Teal. Tilden, Texas, August, October, 1977.

Kuykendal1, William. Tilden, Texas, August, 1977.

Morgan, Thomas. Calliham, Texas, August, 1977.

Potts, Murry. Tilden, Texas, August, 1977.

Reagan, Ott. Calliham, Texas, August, 1977.

Ritter, Gladys. Filden, Texas, August, 1977.

Teal, C. H. San Antonio, Texas, August, 1977.

Walker, Charles E. Tilden, Texas, August, 1977.

Wheeler, Clifton. Tilden, Texas, August, October, 1977.

Wheeler, Gladys. Tilden, Texas, August, October, 1977. 